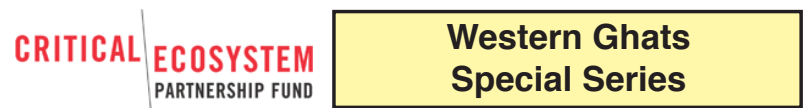

\title{
A new genus of the family Theraphosidae (Araneae: Mygalomorphae) with description of three new species from the Western Ghats of Karnataka, India
}

\author{
Manju Siliwal ${ }^{1}$, Neha Gupta² \& Robert Raven ${ }^{3}$ \\ ${ }^{1}$ Wildlife Information Liaison Development Society, 96 Kumudham Nagar, Vilankuruchi Road, Coimbatore, Tamil Nadu 641035, India \\ ${ }^{2}$ University School of Environmental Management, Guru Gobind Indraprastha University, Sector 16-C, Dwarka, New Delhi 110075, \\ India \\ ${ }^{3}$ Queensland Museum, Grey Street, PO Box 3300, South Brisbane, 4101, Queensland, Australia \\ Email: ${ }^{1}$ manjusiliwal@gmail.com (corresponding author), ${ }^{2}$ neha_11 taurian@rediff.com, ${ }^{3}$ robert.raven@qm.qld.gov.au
}

Date of publication (online): 26 November 2012 Date of publication (print): 26 November 2012 ISSN 0974-7907 (online) | 0974-7893 (print)

Editor: Anonymity requested

\section{Manuscript details:}

Ms \# 03065

Received 20 January 2012

Final received 09 July 2012

Finally accepted 08 November 2012

Citation: Siliwal, M., N. Gupta \& R. Raven (2012). A new genus of the family Theraphosidae (Araneae: Mygalomorphae) with description of three new species from the Western Ghats of Karnataka, India. Journal of Threatened Taxa 4(14): 3233-3254

Copyright: (c) Manju Siliwal, Neha Gupta \& Robert Raven 2012. Creative Commons Attribution 3.0 Unported License. JoTT allows unrestricted use of this article in any medium for non-profit purposes, reproduction and distribution by providing adequate credit to the authors and the source of publication.

Author Details, Author Contribution and Acknowledgements: See end of this article

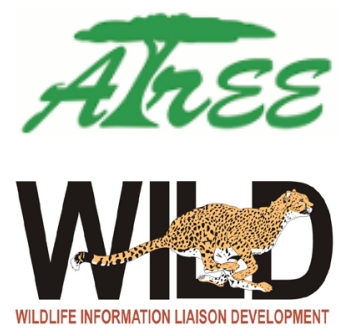

urn:Isid:zoobank.org:pub:698FBB17-F0144EA8-89C9-C5FF1AAA37A5

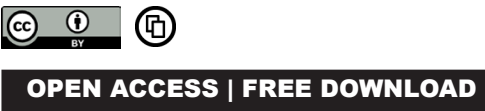

Abstract: In this paper, a new genus Neoheterophrictus gen. nov., with three new species, Neoheterophrictus crurofulvus sp. nov., $N$. sahyadri sp. nov. and $N$. uttarakannada sp. nov., is described from Uttara Kannada District, Karnataka, India. The new genus is close to Heterophrictus Pocock, 1900 and Plesiophrictus Pocock, 1899 but has multilobed spermathecae, which was consistent in all the three species and the males possessing double tibial spur. Natural history information for all the species described is provided. We transfer Plesiophrictus bhori Gravely, 1915 to Heterophrictus and synonymise $P$. mahabaleshwari Tikader, 1977 with Heterophrictus milleti Pocock, 1900.

Keywords: Eumernophorinae, Heterophrictus, new genus, new species, Plesiophrictus, tarantula, taxonomy, Theraphosidae.

\section{INTRODUCTION}

The subfamily Ischnocolinae of the family Theraphosidae is a generic complex and Raven (1985) considered all genera (including the only Indian genus Plesiophrictus Pocock, 1899) as incertae sedis. These genera require re-examination of the type specimens along with examination of new collections from the type locality to revalidate their taxonomic position under Ischnocolinae. Recently, Guadanucci (2011) revalidated the genus Heterophrictus Pocock, 1900 and removed it from the junior synonym of Plesiophrictus; he also provided distinct generic characters for

Abbreviations: $\mathrm{ALE}=$ anterior lateral eye; $\mathrm{AME}=$ anterior median eye; $\mathrm{AT}=$ allotype; $\mathrm{HT}=$ holotype; $\mathrm{MOQ}$ = median ocular quadrate; $\mathrm{MS}$ = Manju Siliwal; NG= Neha Gupta; $\mathrm{PME}=$ posterior median eye PLS = posterior lateral spinnerets; $\mathrm{PMS}=$ posterior median spinnerets; PT = paratype; RR = Robert Raven; STC = superior or paired tarsal claws; WILD = Wildlife Information Liaison Development Society; ZSI = Zoological Survey of India. Abbreviations used for hair and spines count are $d=$ dorsal; fe $=$ femur; $\mathrm{mt}=$ metatarsus; $\mathrm{p}=$ prolateral; $\mathrm{pa}=$ patella; $\mathrm{r}=$ retrolateral; $\mathrm{ta}=$ tarsus; $\mathrm{ti}=$ tibia; $\mathrm{v}=$ ventral.

This article forms part of a special series on the Western Ghats of India, disseminating the results of work supported by the Critical Ecosystem Partnership Fund (CEPF), a joint initiative of l'Agence Française de Développement, Conservation International, the Global Environment Facility, the Government of Japan, the MacArthur Foundation and the World Bank. A fundamental goal of CEPF is to ensure civil society is engaged in biodiversity conservation. Implementation of the CEPF investment program in the Western Ghats is led and coordinated by the Ashoka Trust for Research in Ecology and the Environment (ATREE) 
Heterophrictus and Plesiophrictus, which are helpful in the revision of Indian Plesiophrictus. Though the taxonomic position of Heterophrictus is still confusing in the absence of cladistic analysis (R. Raven pers. comm. 7 February 2012), in this paper, we consider Heterophrictus a valid genus until further cladistic analysis (based on more specimens) is published.

During surveys in Uttara Kannada, Western Ghats of Karnataka, the authors (MS and NG) collected a theraphosid spider where the females had a distinct rastellum. As per published literature, none of the known Indian theraphosids have a cheliceral rastellum. The spider from Uttara Kannada had a combination of characters of the two Indian genera Annandaliella Hirst, 1909 and Plesiophrictus, and the African genus Euphrictus Hirst, 1908. Male specimens of the spider from Uttara Kannada resembled morphologically Annandaliella travancorica Hirst, 1909, but on examining the specimen there were no stridulatory setae between the chelicerae, which is an important generic character for Annandaliella. Furthermore, on looking at unpublished notes based on the examination of type specimens in different European museums, RR had made a special comment for Euphrictus spinosus Hirst, 1908- - "very like Annandaliella but low spur and rastellum present". The spider from Uttara Kannada possesses all these characters including similar palpal bulb morphology, but differs from Euphrictus by the absence of stridulatory spines on the prolateral surfaces of the chelicerae and well-developed double tibial spur being present in males. It also closely resembles Plesiophrictus in male spur structure but there were no spinules or granules between the spurs. After comparing with all the known genera it was clear that it represents a new genus, which is phylogenetically close to Plesiophrictus. The publication of Guadanucci (2011) has cleared many a doubt regarding the genus and helped extensively in the preparation of this paper. The new genus resembles Heterophrictus, but has distinct multilobed spermathecae and well developed double tibial spurs; these characters are consistently found in of all the three different species reported in this paper. Therefore, the spider is assigned to the new genus Neoheterophrictus gen. nov. Probably, Plesiophrictus, Heterophrictus and Neoheterophrictus gen. nov. belong to the same group and are good examples of Gondwana relict taxa.

In the present paper, we describe the new genus
Neoheterophrictus gen. nov. with three new species from the Western Ghats of Karnataka, India. Neoheterophrictus crurofulvus sp. nov. (type species) and $N$. sahyadri sp. nov. are described here based on both the sexes, whereas, N. uttarakannada sp. nov. is based only on female specimens. Although male and female specimens of $N$. sahyadri were collected from different localities, a subadult female was also collected along with the male specimen, and based on its morphological and taxonomic characters, which resembled the mature female, these specimens from different locations were considered conspecific. Natural history notes for all the new species are provided.

\section{METHODS}

All specimens are deposited at Wildlife Information Liaison Development Society, Coimbatore, Tamil Nadu, India. Measurements of body parts, except for the eyes, were made with a Mitutoyo ${ }^{\mathrm{TM}}$ Vernier Calliper. Eye measurements were done with calibrated ocular micrometer. All measurements are in millimetres. Spermathecae were dissected and cleared in concentrated lactic acid in a $100^{\circ} \mathrm{C}$ water bath for 15-20 minutes. Total length excludes chelicerae. All illustrations were prepared with the help of a camera lucida attached to a MOTIC ${ }^{\mathrm{TM}}$ stereomicroscope by MS and NG. The taxonomic description style follows Siliwal \& Molur (2009). All photographs by Manju Siliwal.

\section{TAXONOMY}

\section{Neoheterophrictus gen. nov. Siliwal \& Raven}

urn:Isid:zoobank.org:act:85A3DBB9-5357-45C2-AB75-CB2BB502AE44

\section{Diagnosis}

The new genus closely resembles Heterophrictus in the absence of serrula, procurved fovea, presence of rastellum on chelicerae, scopulae on tarsi I-IV divided with setae but differs in spermathecae structure, two receptacles, with many lobes/termini at the apex; it also closely resembles Plesiophrictus by presence of two tibial spurs, each with a pointed spine and female scopulae on tarsi I-IV divided with 
setae, but differs from Plesiophrictus by serrula being absent; fovea procurved; presence of rastellum on chelicerae; spermathecae structure, two receptacles with many lobes at the apex; tegular keel absent on male palpal bulb; absence of a row of stout black granules between primary and secondary spur; male ta I-III divided by a row of hairs and ta IV divided by a band of setae; presence of prolateral brush of large feathery hair (appearing like scopulae from lateral view) on distal half of coxae, trochanter to patella of leg I and on retrolateral distal half of trochanter to tibia and a band on prolateral femorae of palp. The new genus differs from the genus Ischnocolus and African genus Heterothele by presence of tibial spur (absent in Ischnocolus); differs from Afro-European genera Chaetopelma and Nesiergus by primary tibial spur with only a single spine at its tip.

\section{Description}

Spider covered with a mat of short hair (grey/ brown/pallid), more dense on carapace, chelicerae and abdomen than on legs, sternum, maxillae, labium and spinnerets. Cephalic region weakly raised. Eyes on ocular tubercle. Fovea slightly procurved. Clypeus very narrow or absent. Rastellum present on anterior dorsoprolateral edge of chelicerae, distinct in female and greatly reduced in male. All legs subequal in thickness; tibiae to tarsi of leg IV covered with many long hairs; metatarsi and tarsi of leg III and IV heavily spined. Thorn setae present on prolateral coxae I and above suture band of setae partially covered with brush of grey hair. Brush of large feathery hair (appearing like scopulae from lateral view) on prolateral distal half of coxae, trochanter to patella of leg I and on retrolateral distal half of coxae, trochanter to tibia and band on prolateral femorae of palp. Tarsal scopulae on all legs divided in females with band of setae, which gets broader distally, in male tarsi I-III divided with single row of hair and tarsi IV divided with band of setae. Male with double tibial spur on ventral side of tibia I, primary spur, long, gradually narrowing down towards apex, with prominent spine at tip; secondary spur rounded at apex with numerous bristles, hairs and a few tubercles on inner side, long curved spine emerge at base of secondary spur, covering spur on its retrolateral aspect. Male palp simple, palpal bulb simple without any keel or protrusions, embolus long, gradually tapering towards tip and without keels.
Spermathecae, two receptacles, each with many lobes at apex (resembling sketch of a tree).

\section{Etymology}

The name is a combination of two words 'neo' and 'heterophrictus', neo in Latin meaning new and 'heterophrictus' is a genus name within the family Theraphosidae to which the new genus resembles.

\section{Type species}

Neoheterophrictus crurofulvus sp. nov., based on female and male specimens deposited at WILD, Coimbatore, Tamil Nadu.

\section{Species included}

Neoheterophrictus crurofulvus sp. nov., N. sahyadri sp. nov., and N. uttarakannada sp. nov.

\section{Distribution}

Western Ghats, India.

Neoheterophrictus crurofulvus sp. nov.

(Images 1-2, Figs. 1A-I, 2A-J, 3A-D, Table 1-2, Appendix 1)

urn:Isid:zoobank.org:act:F5A6C6B8-A2A6-4C30-BCD1-CEED1ECC3BAE

\section{Type material:}

Holotype: female, 5.v.2010, Kulgi, Dandeli Wildlife Sanctuary, Uttara Kannada, Karnataka, India $\left(15.167028^{\circ} \mathrm{N} \& 74.617083^{\circ} \mathrm{E}, 521 \mathrm{~m}\right)$, coll. M. Siliwal, S. Chauhan, K. Ramesh, WILD-10-ARA-1067.

Allotype: male, 10.xii.2009, same data as holotype, coll. M. Siliwal, S. Behera, WILD-09-ARA-472.

Paratypes: 4 females, same data as holotype, WILD-10-ARA-1061, WILD-10-ARA-1065, WILD10-ARA-1066, WILD-10-ARA-1088; 1 female, 22.xi.2009, near Nagoda forest guest house, Joida, Uttara Kannada, Karnataka, India $\left(15.19280^{\circ} \mathrm{N}\right.$, $74.617083^{\circ} \mathrm{E}, 584 \mathrm{~m}$ ), coll. M. Siliwal, S. Behera, WILD-09-ARA-420; 1 male, same data as allotype, WILD-09-ARA-473; 2 juveniles, 1-5.v.2010, same data as holotype, coll. M. Siliwal, S. Chauhan, K. Ramesh, WILD-10-ARA-1081, WILD-10-ARA-1082.

\section{Diagnosis}

Female differs from other known species in spermathecae structure (Fig. 1I), two receptacles, each long slightly narrowing down at apex, many very 


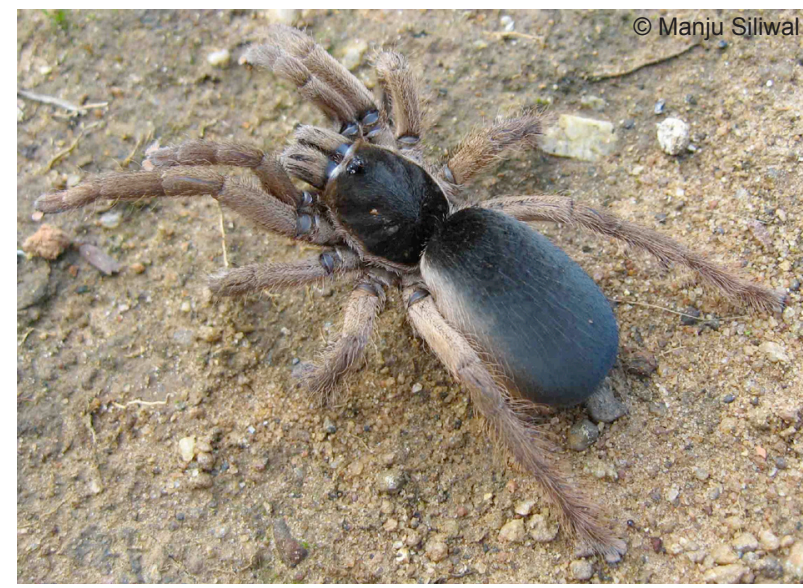

Image 1. Female of Neoheterophrictus crurofulvus sp. nov. (Paratype, WILD-09-ARA-420)

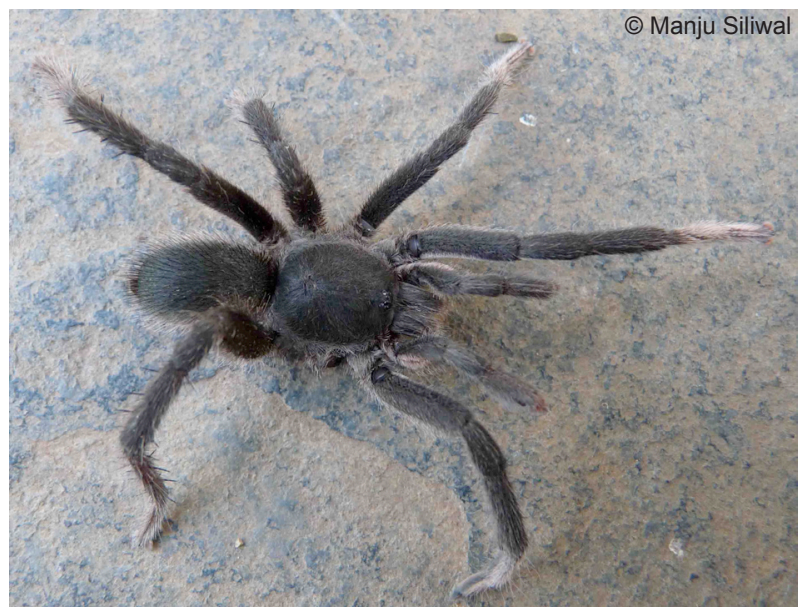

Image 2. Male of Neoheterophrictus crurofulvus sp. nov. (WILD-09-ARA-472)
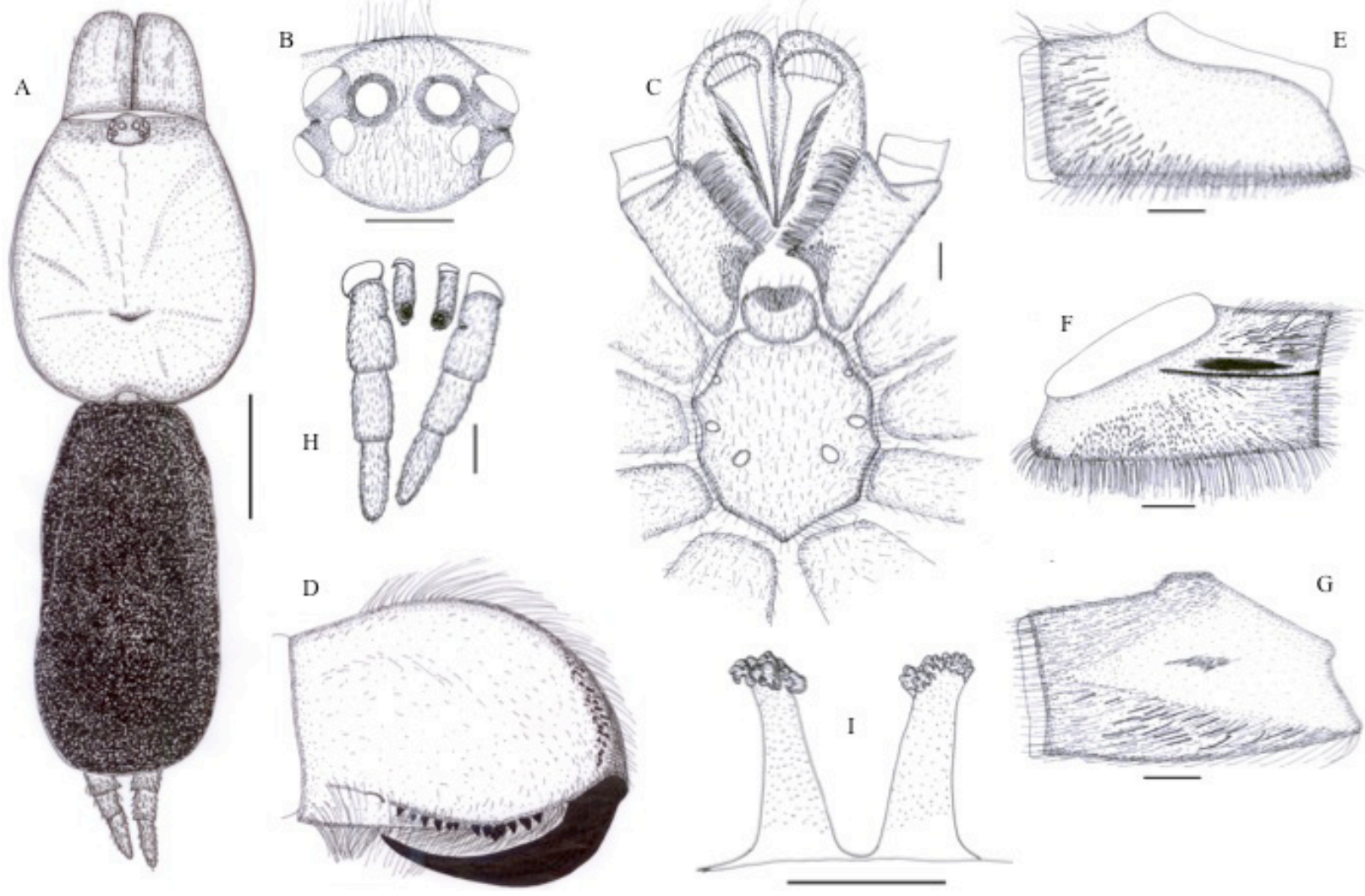

Figure 1. Neoheterophrictus crurofulvus sp. nov., female (WILD-10-ARA-1067). A - Carapace and abdomen dorsal view; B - Eye; C - Sternum, maxillae, labium, chelicerae; D - Chelicerae prolateral view; E - Maxillae, retrolateral view; F - Coxa I, prolateral view; G - Coxa I, retrolateral view; H - Spinnerets; I - Spermathecae. Scale $1.0 \mathrm{~mm}$ for B-I and scale $0.5 \mathrm{~mm}$ for A.

small or minute lobes at apex resembling inflorescence of flower; legs, chelicerae, margins of carapace and ventral and lateral sides of abdomen coffee brown, rest black in life (Image 1).

Male of the new species differs by primary tibial spur narrowing down gradually towards apex with pointed spine at the tip; absence of thick spine at the base of primary tibial spur (Fig. 2J) on retrolateral aspect; distal two-third of metatarsi and complete tarsi of all legs is white (Image 2). 


\section{Etymology}

The species name is a combination of two Latin words, 'cruro' (for legs or limbs) and 'fulvus' (for tawny or yellowish-brown). Crurofulvus refers to the light brown legs of the female spider, which is not seen in any other known Indian theraphosid.

\section{Description of holotype female (WILD-10- ARA-1067)}

Female: Carapace 11.41 long, 9.51wide, chelicerae 6.64 long. Abdomen 14.25 long, 7.09 wide. Spinnerets: PMS, 1.14 long, 0.45 wide, 0.56 apart; PLS, 1.98 basal, 1.46 middle, 1.73 apical, mid-width $0.81,0.76$, 0.58 respectively, 5.17 total length. Leg and palp morphometry in Table 1.

Colour in life (Image 1): Carapace, dorsal base of chelicerae and dorsal side of abdomen black, reflects greyish shade in light. Legs, chelicerae, margins of carapace and ventral and lateral sides of abdomen along with long hairs pale/coffee brown. Leg IV appears to be incrassate in life because of presence of long hair (not as dense as seen in Lyrognathus).

Carapace (Fig. 1A): Length to width ratio 1.20; reddish-brown, lighter towards periphery; covered with a strong mat of short black hairs, more dense towards margins and concentrated along striae radiating from fovea, long, curved, light brown hairs at periphery. Bristles: 11 long on caput in mid-dorsal line; 5 long anteromedially; 9 long, 5 short between PME; 11 long, 8 short on clypeus edge. Mat of fine hair on anterior and posterior ocular area, fine golden hair at base of PLE. Fovea deep, slightly procurved. Two glabrous bands emerging from anteriolateral sides of carapace, on either side of caput, broadens posteriorly and ends up much before fovea. Caput not much higher than cephalic and thoracic region.

Eyes (Fig. 1B): Group occupies 0.26 of headwidth; ratio of group width to length 1.89. ALE clearly larger than rest, PME clearly smaller than rest. Eyes on ocular tubercle. Eye diameter: ALE, 0.42; AME, 0.36; PLE, 0.33; PME, 0.19. Distance between eyes: AME-AME, 0.17; PME-PLE, adjacent; AME-ALE, 0.08; PME-PME, 0.69. Ocular Quadrate, 0.89 long, 1.68 wide. MOQ: length, 0.71 ; front width, 0.89 ; back width, 1.05. Clypeus absent.

Maxillae (Fig. 1C,E): 3.46 long in front, 4.56 long in back, 2.18 wide. Posterior edge near heel concave; anterior lobe distinct, serrula absent, long bristles present; posterior ventral edge straight. Cuspules: ca. 200 sparsely arranged in anterior corner in triangle region. Prolateral face, scattered short and long hair present, a few short setae above maxillary suture, setae and bristles absent. Retrolateral face reddish-orange, glabrous in centre with thin short (stiff black bristles) spines on distal quarter, posterior and retroventral edge.

Labium (Fig. 1C): 1.55 long, 1.94 wide; ca. 100 cuspules in band for one-fourth of length anteriorly; cuspules similar in size to those on maxillae. Basal groove shallow, distinct. Labiosternal groove convex. One pair of large sigilla present in labiosternal groove but not meeting in centre.

Chelicerae (Fig. 1D): Intercheliceral spines absent. Chelicerae lyra absent. Prolateral, not smooth, band with sparsely covered hairs running on curved chelicerae shape just below dorso-prolateral face with 3-4 stiff bristles at base; retrolateral faces glabrous, reddish-brown; 12 promarginal teeth, 42 basomesal teeth. Rastellum present, 33 short thick curved spines in 2-3 rows present on dorsoprolateral edge of chelicerae.

Sternum (Fig. 1C): 5.20 long, 4.80 wide. Almost round, high in centre, sloping gradually, covered with long and short brown hair. Posterior angle short, blunt and not separating coxae IV. Posterior edge clearly seen. Prostrate hair mat strong, dense, of pallid hairs. Single row of long black bristles like hair present on margins. Pedicel pallid, not seen properly.

Sigilla (Fig. 1C): 3 pairs, posterior, oval, 0.31 diameter, ca. 2.16 apart, 1.01 from margin; middle, oval, 0.25 diameter, 3.58 apart, 0.39 from margin; anterior, very small, round, marginal.

Legs: Formula 4123. Leg I clearly thicker than IV, II subequal to IV. Basifemoral thorns absent on all. Mat of short feathery hair (Image 1, resembling scopulae hair) present on prolateral side of distal half of coxae, trochanter to basal half of patella of leg I and on retrolateral side of distal half of coxae, trochanter to tibia of palp (not as dense as on leg I). Metatarsus III 1.5 times longer than tarsus, metatarsus IV 2.00 times longer than tarsus, rest slightly longer (1.30 times) than tarsi.

Spines: I: ti, v=2; mt, v=1. II: ti, $p=1, v=3 ; \mathrm{mt}, \mathrm{p}=1$, $\mathrm{v}=4$. III: $p a, p=1, \mathrm{ti}, \mathrm{p}=1, \mathrm{v}=3, \mathrm{r}=1 ; \mathrm{mt}, \mathrm{p}=2, \mathrm{v}=6, \mathrm{r}=2$. IV: ti, $p=1, v=4, r=4 ; m t, p=3, v=9, r=3$. Palp: ti: $v=2$. Spines on distal metatarsi: I, 1 distal ventral; II-III-IV, 
1 distal ventral, 2 distal ventrolateral.

Trichobothria: Tarsi: I, 30 clavate, 16 long and short filiform; II, 30 clavate, 24 long and short filiform; III, 24 clavate, 24 long and short filiform; IV, 14 clavate, 20 long and short filiform; palp, 23 clavate, 12 long and short filiform. Clavate on I-IV in distal threequarters in two rows; filiforms only in basal threequarters. Short epitrichobothrial hair field on tarsi as wide as clavates and uniform height for length.

Coxae (Figs. 1F-G): Coxal bases dorsally easily seen from above (Image 1). I longest, about 1.33 times length of II; IV clearly widest and basally with anterior corner distinct, edge curves dorsally, rounded at interface. Coxae ventrally with short golden brown hair, weak thorns present on prolateral faces of I-II and very much reduced on III-IV, sparsely distributed in basal one half portion on coxae I, one fourth basal on coxae II, very few on proventral basal edge; above suture thick blackish-brown long thick stiff setae along with brush of fine grey hair on leg I-II, on IIIIV reduced to a few setae. I-IV ventrally covered with golden brown mat of small hairs at base of coxa, long and short black and pallid hair, all coxae sloping backward. Retrolateral setation: I-III with median narrow light thin brush of pallid hair, IV glabrous.

Leg pilosity: Leg III-IV, tibia to tarsi covered with long hairs, leg IV appears incrassate. Femorae of all legs have pallid brush like long hair ventrally. All legs covered with mat of greenish-brown short hair. Number of long hairs extending well above base layer, I: $\mathrm{pa}, \mathrm{v}=4 ; \mathrm{ti}, \mathrm{d}=4, \mathrm{p}=3, \mathrm{v}=8, \mathrm{r}=2 ; \mathrm{mt}, \mathrm{d}=5, \mathrm{p}=4, \mathrm{v}=3$, $\mathrm{r}-2$; ta, $\mathrm{d}=2$. II: $\mathrm{pa}, \mathrm{d}=2, \mathrm{v}=4$; ti, $\mathrm{d}=7, \mathrm{p}=4, \mathrm{v}=8, \mathrm{r}=3$; mt, $d=9, p=2, v=5, r=3$; ta, $d=2$. III: $p a, d=5, p=6, v=3$, $r=6 ; \mathrm{ti}, \mathrm{d}=7, \mathrm{p}=12, \mathrm{v}=26, \mathrm{r}=16 ; \mathrm{mt}, \mathrm{d}=18, \mathrm{p}=7, \mathrm{v}=21$, $r=14$; ta, $d=2, p=2, r=2$. IV: $p a, d=8, p=10, v=4, r=17$; ti, $d=28, p=32, v=24, r=48 ; m t, d=38, p=40, v=34$, $\mathrm{r}=80$; ta, $\mathrm{d}=24, \mathrm{p}=14, \mathrm{r}=36$.

Scopulae: Entire on all tarsi, divided with setae, division broader distally; ta I, divided centrally with $2-3$ setae (distally with band of 6-8 setae), ta II-III, divided with band of 3-4 (distally 12-16) setae, ta IV, divided with band of 5-6 (distally 16-20) setae; $\mathrm{mt} \mathrm{I}$, distal three-quarters; mt II, distal half; mt III-IV, distal quarter, scanty. Metatarsi scopulae intermixed with long black hair and bristles. No scopula on proventral tibiae.

Tarsal weakness: Not prominent.

Claws: Paired claws on leg I-IV without dentition 
Table 2. Neoheterophrictus crurofulvus sp. nov., measurements of legs and palp of male specimens, allotype (WILD-09ARA-472) and paratype (WILD-09-ARA-473)

\begin{tabular}{|l|c|c|c|c|c|c|c|c|c|c|c|}
\hline & \multicolumn{2}{|c|}{ Leg I } & \multicolumn{2}{c|}{ Leg II } & \multicolumn{2}{c|}{ Leg III } & \multicolumn{2}{c|}{ Leg IV } & \multicolumn{2}{c|}{ Palp } \\
\hline & AT & PT & AT & PT & AT & PT & AT & PT & \multicolumn{2}{|c|}{ AT } & PT \\
\hline Femur & 9.45 & 8.05 & 8.12 & 7.19 & 7.33 & 6.28 & 10.2 & 8.71 & 5.46 & 5.08 \\
\hline Patella & 4.83 & 4.65 & 4.57 & 3.61 & 4.06 & 3.45 & 4.79 & 4.11 & 2.79 & 2.86 \\
\hline Tibia & 7.22 & 6.45 & 5.27 & 4.76 & 4.43 & 4.100 & 7.8 & 7.04 & 4.33 & 3.74 \\
\hline Metatarsus & 6.34 & 5.34 & 5.27 & 4.76 & 6.34 & 5.25 & 10.92 & 9.23 & - & - \\
\hline Tarsus & 2.60 & 2.77 & 2.78 & 2.76 & 3.04 & 3.06 & 3.66 & 3.36 & 1.03 & 1.11 \\
\hline Total & 30.44 & 27.26 & 26.01 & 23.08 & 25.2 & 22.14 & 37.37 & 32.45 & 13.61 & 12.79 \\
\hline Midwidth & \multicolumn{7}{|l|}{} \\
\hline Femur & 1.86 & 1.5 & 2.08 & 1.78 & 2.38 & 1.85 & 2.23 & 1.7 & 1.42 & 1.26 \\
\hline Tibia & 1.89 & 1.41 & 1.52 & 1.21 & 1.64 & 1.39 & 1.72 & 1.27 & 1.41 & 1.33 \\
\hline
\end{tabular}

and single bare claw on palp. Claw tufts well developed but not obscuring claws.

Abdomen pilosity (Image 1): cuticle not exposed dorsally and ventrally; dorsally covered with a thick mat of black hair, a fine layer of brown long and short hair, many pallid; ventrally and ventrolateral uniformly greenish-brown, thick mat of fine pallid hair, intermixed uniformly with long pallid and golden hair. Abdomen slightly broader posteriorly.

Spinnerets (Fig. 1H): Two pairs, digitiform, yellowish with brown hairs.

Spermathecae (Fig. 1I): Two receptacles with multiple minute lobes (like inflorescence of flower) at apex. Each receptacle, long, broader at base, slightly tapering towards apex (like a tree trunk).

\section{Variations in female paratypes $(\mathbf{n}=\mathbf{5})$ :}

Total length: $20.33-25.78$ (23.81 \pm 2.23$)$. Carapace: 10.14-11.58 (10.81 \pm 0.54$)$ long, 7.92-9.65 (9.18 \pm 0.71$)$ wide. Ocular group: $0.58-0.65$ (0.62 \pm 0.03$)$ long, 1.50-1.64 (1.59 \pm 0.06$) \quad$ wide. MOQ: $0.50-0.73$ (0.64 \pm 0.10$)$ long, front width $0.61-0.95(0.77 \pm 0.15)$, back width $0.96-1.19(1.05 \pm 0.10)$. Labium: $1.12-1.55$ (1.26 \pm 0.17$)$ long, $1.27-1.94(1.46 \pm 0.28)$ wide; 55100 cuspules. Sternum: 4.65-5.43 (5.07 \pm 0.31$)$ long, 3.87-5.24 (4.74 \pm 0.52$)$ wide. Maxillae: 1.73-3.46 (2.50 \pm 0.63$)$ long in front, $2.62-4.56(3.38 \pm 0.74)$ long in back, 2.18-4.35 (3.33 \pm 0.95$)$ wide; cuspules 150 280. Abdomen: 10.19-14.25 (13.02 \pm 1.70$)$ long, 6.01$7.63(6.86 \pm 0.59)$ wide. Leg and palp morphometry in Table 1.

\section{Description of allotype male (WILD-09-ARA-472):}

Total length 20.64. Carapace 10.28 long, 8.84 wide, chelicerae 5.53 long. Abdomen 10.36 long, 5.26 wide. Spinnerets: PMS, 1.40 long, 0.27 wide, 0.52 apart; PLS, 1.43 basal, 0.92 middle, 1.09 apical, midwidth $0.69,0.41,0.32$ respectively, 3.44 total length. Leg and palp morphometry in Table 2.

Colour in life (Image 2): Carapace, chelicerae and dorsal side of abdomen greenish-black. Carapace margin lighter. Legs greyish-black except for distal two-third of metatarsi of legs and tarsi of legs and palp white (brighter on anterior legs than posterior legs and palp). Chelicerae and dorsal side of coxae and trochanter creamish/pallid. Legs and abdomen covered with long pallid hairs and black bristles with orange tips.

Carapace (Fig. 2A): Length to width ratio 1.16; reddish-brown, lighter at periphery; covered with a strong mat of short golden brown hairs intermixed with short black hairs, more dense towards margins and concentrated along interstitial ridges radiating from fovea, long curved light brown bristles with pallid tips at periphery on posterior half of carapace. Bristles: 4 long, 9 short anteromedially; 4 long, 7 short between PME; 12 long, 11 short on clypeus edge. Mat of fine hair on anterior and posterior ocular area, fine golden hair at base of PLE. Fovea deep, slightly procurved. Two glabrous bands emerging from anteriorlateral sides of carapace, on either side of caput, broadens posteriorly and ends before fovea. Caput not much higher than cephalic and thoracic region.

Eyes (Fig. 2B): Group occupies 0.29 of headwidth; ratio of group width to length 1.81. ALE clearly 

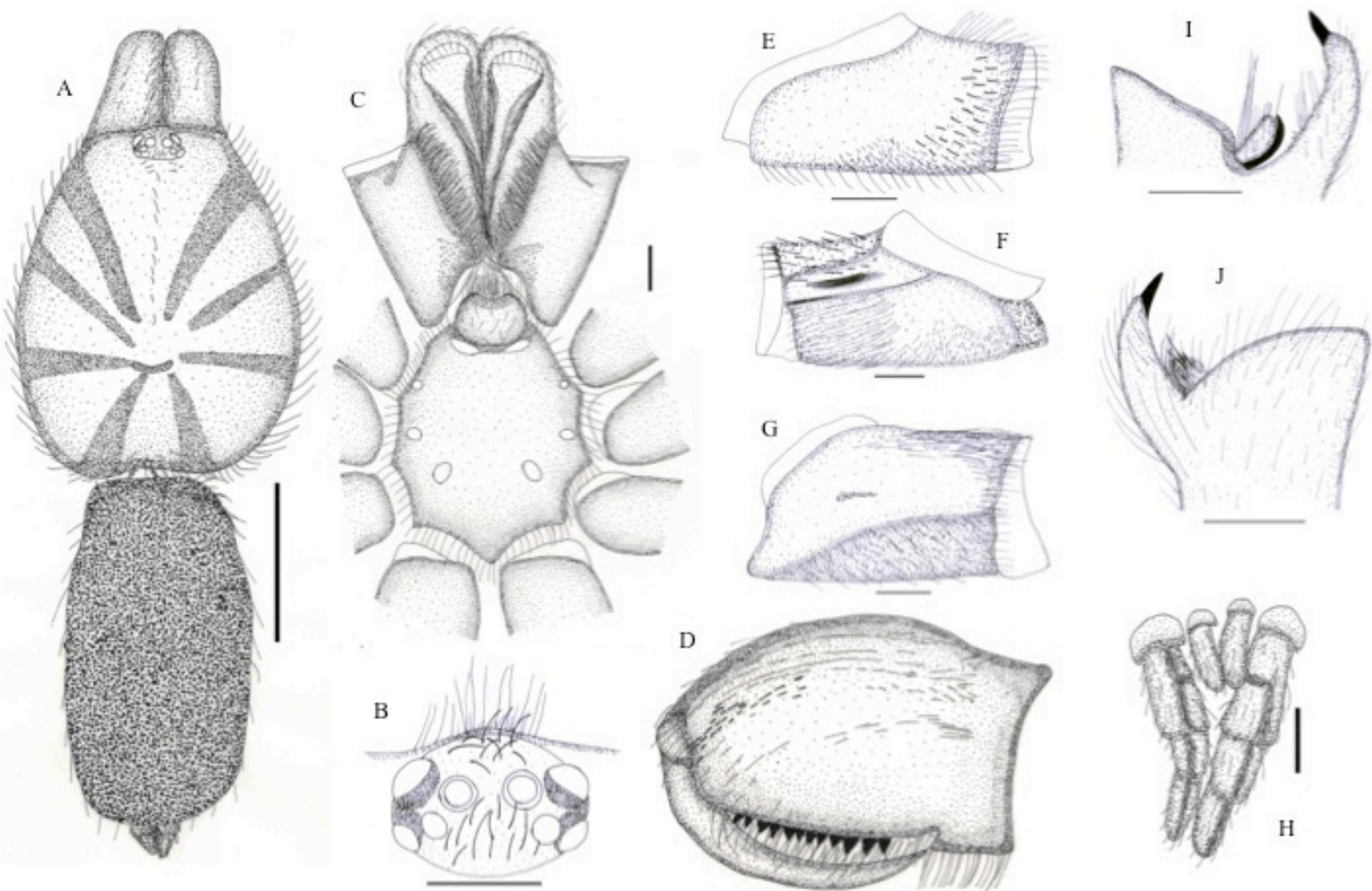

Figure 2. Neoheterophrictus crurofulvus sp. nov., male (WILD-09-ARA-472).

A - Carapace and abdomen dorsal view; B - Eye; C - Sternum, maxillae, labium, chelicerae; D - Chelicerae prolateral view; E - Maxillae, retrolateral view; F - Coxa I, prolateral view; G - Coxa I, retrolateral view; H - Spinnerets; I - Tibial spur, prolateral view; J - Tibial spur, retrolateral view. Scale $1.0 \mathrm{~mm}$ for B-J and scale $0.5 \mathrm{~mm}$ for A.

larger than rest, PME smaller than anterior eyes. Eyes on ocular tubercle. Eye diameter: ALE, 0.35; AME, 0.29; PLE, 0.27; PME, 0.25. Distance between eyes: AME-AME, 0.12; PME-PLE, adjacent; AME-ALE, 0.05; PME-PME, 0.58. Ocular Quadrate, 0.66 long, 1.20 wide. MOQ: length, 0.58 ; front width, 0.80 ; back width, 0.95; difference between back and front width, 0.15 . Clypeus very narrow.

Maxillae (Fig. 2C,E): 2.64 long in front, 3.72 long in back, 1.83 wide. Posterior edge near heel concave, anterior lobe distinct, serrula absent, long bristles present; posterior ventral edge straight. Cuspules: ca. 190 in anterior corner in triangle region. Prolateral face, scattered short and long hair present, few short stiff hair above maxillary suture, setae and bristles absent. Retrolateral face reddish-orange, glabrous in centre with thin short (stiff black bristles) spines on distal quarter, posterior and retroventral edge.

Labium (Fig. 2C): 0.89 long, 1.34 wide; ca. 80 cuspules in band for one-fourth of length anteriorly; cuspules similar in size to those on maxillae. Basal groove shallow, distinct. Labiosternal groove convex. One pair of large sigilla present in labiosternal groove.

Chelicerae (Fig. 2D): 5.53 long, intercheliceral spines absent. Chelicerae lyra absent. Prolateral, not smooth, band with faint ridges (at the half way point of band), sparsely covered with hairs running on curved chelicerae shape in just below dorso-prolateral face with 3-4 stiff bristles at base; retrolateral faces glabrous, reddish-brown; 16 promarginal and 39 basomesal teeth in 2-4 rows. Rastellum present, not as prominent as in female, 18 short and long thick, curved bristle-like spines in 2-3 rows on dorsoprolateral edge of chelicerae.

Sternum (Fig. 2C): 4.62 long, 4.39 wide. Slightly oval (more roundish), broader posteriorly, high in centre, sloping gradually, covered with long and short brown hair. Posterior angle short and blunt and not separating coxae IV. Posterior edge clearly seen. A few scattered small pallid hair covering base of sternum like mat but not dense and not covering sternum. 2-3 
rows of long black bristle-like hair present on margins posteriorly. Pedicle pallid, not seen properly.

Sigilla (Fig. 2C): Three pairs, posterior sigilla, oval, 0.37 diameter, ca. 1.41 apart, 0.60 from margin; median sigilla, oval, 0.29 diameter, 3.24 apart, 0.12 from margin; anterior, very small, round, marginal.

Legs (Figs. 2I-J): Formula 4123. All legs almost subequal in thickness. Basifemoral thorns absent on all. Mat of short feather hair (Image 2, resembling scopulae hair) present on prolateral side of distal half of coxae, trochanter to basal half of patella of leg I and on retrolateral side of distal half of coxae, trochanter to tibia of palp (not as dense as on leg I). Mt IV 2.98 times longer than ta IV, rest 2.00-2.40 times longer than ta. Tibial apophysis consists of two spurs ventrally, primary spur on ventro-retrolateral surface, long, gradually narrowing down slightly towards apex, with prominent spine at tip; secondary spur on ventroprolateral aspect of primary spur, rounded at apex with numerous bristles, hairs and a few tubercles on the inner side of it, long curved spine emerge at base of secondary spur, covering spur on its retrolateral aspect. No granules or spines present between two spurs.

Spines: I: ti, v=2 spur, each with pointed spine; mt, v=1. II: ti, $p=1, v=3$; mt, $p=1, v=3$. III: ti, $p=r=1$, $\mathrm{v}=4 ; \mathrm{mt}, \mathrm{p}=\mathrm{r}=2, \mathrm{v}=5$. IV: ti, $\mathrm{p}=3, \mathrm{r}=1, \mathrm{v}=4 ; \mathrm{mt}, \mathrm{p}=\mathrm{r}=3$, $\mathrm{v}=5$. Spines on distal metatarsi: I, 1 ventral; II, 2 ventrolateral; III-IV, 1 ventral, 2 ventrolateral.

Trichobothria: ta I, 25 clavate, 10 long and 10 short filiform; ta II, 23 clavate, 10 long and 20 short filiform in 2 rows for length; ta III, 22 clavate, 12 long and 13 short filiform; ta IV, 22 clavate, 14 long and 20 short filiform and 15 clavate, 8 long and 6 short filiform on palp. Clavate on I-IV in distal three-quarters in two bands; filiforms for length. Short epitrichobothrial field on all legs as wide as clavates and uniform height for length.

Coxae (Fig. 2F-G): Coxal bases dorsally easily seen from above. I longest, about 1.30 times longer than II; IV clearly widest and basally with anterior corner distinct, edge curves dorsally, rounded at interface. I-IV ventrally covered with short golden brown hair at base accompanied by long and short black and pallid hair, weak thorns present on prolateral faces of I-II but not as dense as in female and very much reduced on III, absent on IV, sparsely distributed in basal one half portion on coxae I, one fourth basal on coxae II, very few on proventral basal edge; above suture thick
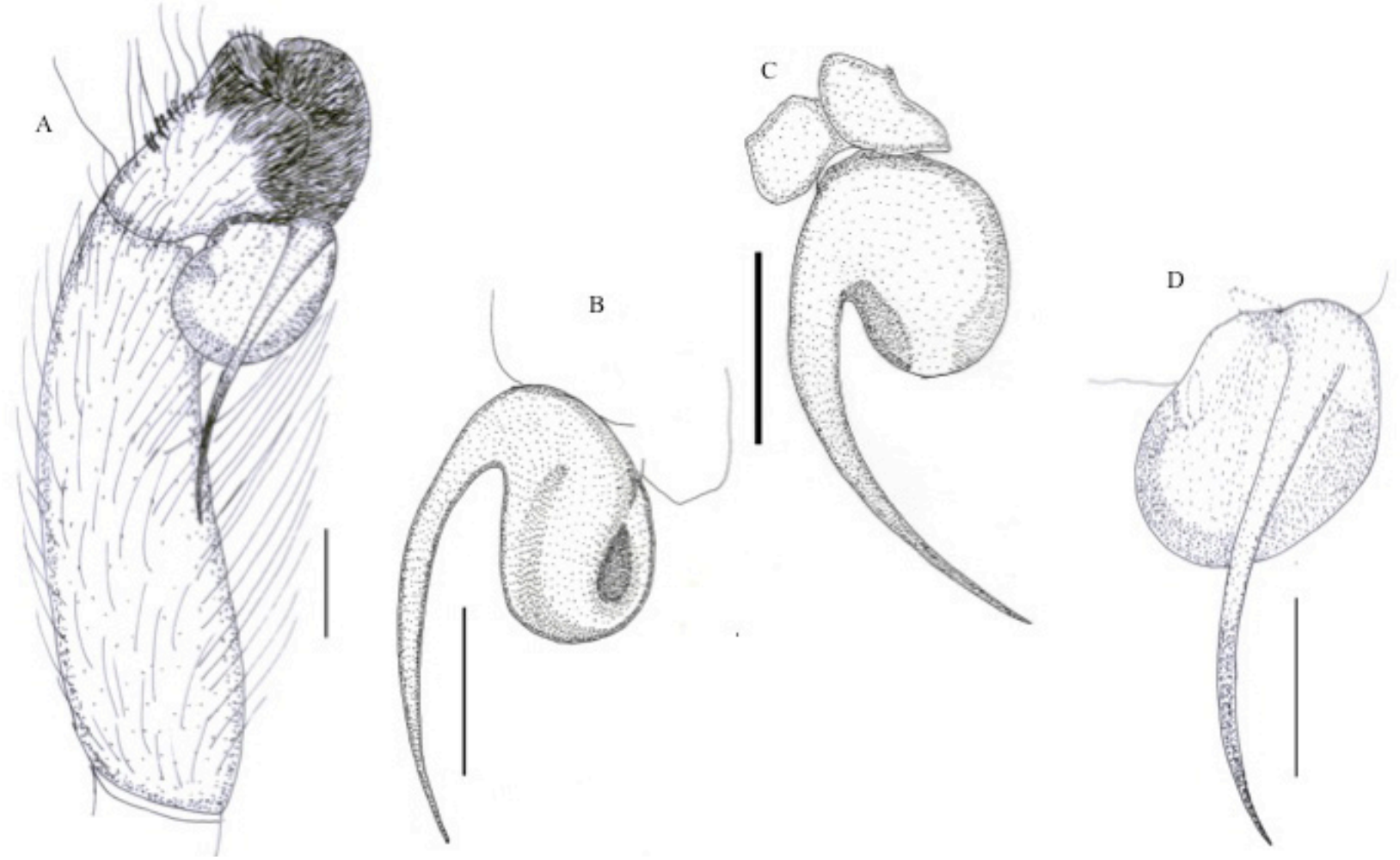

Figure 3. Neoheterophrictus crurofulvus sp. nov., male (WILD-09-ARA-472).

A - Tibia to Palp, retrolateral view; B - Palp, Prolateral view; C - Palp, retroventral view; D - Palp, retrolateral view. Scale $1.0 \mathrm{~mm}$ for A-D. 
blackish-brown long thick stiff setae along with brush of fine grey hair on I, reduced on II, only few setae on III-IV. I-II slopping forward and III-IV backward. Retrolateral setation: I-III with median narrow light brush of pallid hair, IV glabrous.

Leg pilosity: All legs not very hairy, III-IV relatively more hairy than I-II. Femorae of all legs ventrally have pallid brush like long hairs. All legs covered with mat of greenish-brown short hairs along with black bristles and pallid hairs. Number of long hairs extending well above base layer, I: fe $\mathrm{p}=\mathrm{d}=\mathrm{r}=10$ , $\mathrm{v}=50$; $\mathrm{pa}, \mathrm{p}=\mathrm{r}=2, \mathrm{~d}=5, \mathrm{v}=7$; ti, $\mathrm{p}=5, \mathrm{~d}=15, \mathrm{r}=7, \mathrm{v}=20$; $\mathrm{mt}, \mathrm{d}=\mathrm{v}=10, \mathrm{p}=\mathrm{r}=7$; ta, $\mathrm{d}=6, \mathrm{p}=3, \mathrm{r}=3$. II: fe $\mathrm{d}=12, \mathrm{p}=4$, $\mathrm{r}=10, \mathrm{v}=30 ; \mathrm{pa}, \mathrm{d}=4, \mathrm{p}=2, \mathrm{r}=6, \mathrm{v}=5 ; \mathrm{ti}, \mathrm{d}=12, \mathrm{p}=\mathrm{r}=6$, $\mathrm{v}=20 ; \mathrm{mt}, \mathrm{d}=15, \mathrm{p}=4, \mathrm{r}=6, \mathrm{v}=14 ; \mathrm{ta}, \mathrm{d}=10, \mathrm{p}=4, \mathrm{r}=2$. III: fe, $d=10, p=7, r=20, v=30 ; p a, d=r=4, p=v=2 ; t$, $\mathrm{d}=\mathrm{r}=10, \mathrm{p}=4, \mathrm{v}=20 ; \mathrm{mt}, \mathrm{d}=12, \mathrm{p}=4, \mathrm{v}=10, \mathrm{r}=7$; ta, $\mathrm{d}=3$, $\mathrm{p}=5, \mathrm{r}=6$. IV: fe, $\mathrm{d}=\mathrm{p}=10, \mathrm{v}=25, \mathrm{r}=20 ; \mathrm{pa}, \mathrm{d}=6, \mathrm{p}=\mathrm{r}=5$, $\mathrm{v}=4 ; \mathrm{ti}, \mathrm{d}=8, \mathrm{p}=16, \mathrm{v}=30, \mathrm{r}=10 ; \mathrm{mt}, \mathrm{d}=30, \mathrm{p}=20, \mathrm{v}=25$, $\mathrm{r}=50$; ta, $\mathrm{d}=15, \mathrm{p}=10, \mathrm{v}=2, \mathrm{r}=15$.

Scopulae: Entire on all tarsi, intermixed with hair and divided with hair on I-III and divided by setae on IV, division broader distally, dividing setae brown with pallid tips and hair pallid; ta I-III, only one setae (distal with band of 3-4 setae), ta IV, divided with band of 4-5 (distally 8-9) setae. Mt I, distal three-quarters; met II, distal half; mt III-IV, distal quarter, scanty. Metatarsi scopulae intermixed with long black hair and bristles. No scopula on proventral tibiae.

Tarsal weakness: Not prominent.

Claws: Paired claws on leg I-IV without dentition and single bare claw on palp. Claw tufts well developed but not obscuring claws.

Abdomen pilosity (Image 2): Cuticle not exposed dorsally and ventrally; dorsally covered with a thick mat of brown hair, a fine layer of black, brown long and short hair, many pallid; ventrally and ventrolateral uniformly greenish-brown, thick mat of fine pallid hair, intermixed uniformly with long pallid hair.

Spinnerets (Fig. 2H): Two pairs, digitiform, yellowish covered with brown hairs.

Palp (Figs. 3A-D): Tarsi divided distally but not deep. Bulb large and twisted on cymbium with long embolus. Embolus emerges from posterioventral area of the tegulum, takes $180^{\circ}$ bend and gradually tapers towards the tip, diverting away from the bulb.

\section{Variations in male paratype}

Total length: 18.79. Carapace: 8.73 long, 7.53 wide. Ocular group: 0.65 long, 1.26 wide. MOQ: 0.50 long, front width 0.68 , back width 0.84 . Labium damaged. Sternum: 3.98 long, 3.59 wide. Maxillae: 2.97 long in front, 3.59 long in back, 1.99 wide; cuspules 155. Abdomen: 10.06 long, 6.36 wide. Leg and palp morphometry in Table 2 .

\section{Natural History}

Males of the species were found in mixed forest and semievergreen patch of forest under decaying logs or rocks with $60-70 \%$ of canopy cover, $30-80 \%$ ground cover (based on season) and $0-20 \%$ rock cover. No male was found in the burrow. Females were found in burrows constructed vertically on sloping ground (15$40^{\circ}$ ), burrows were facing sloping direction and were mostly found around the base of large trees or decaying logs. Burrows of female resembled those of Arctosa spp. (Lycosidae) with minimal silk (few strands) at the entrance and inside the burrow. The first female was found wandering on a katchcha (unmetalled, country) road, near a fresh landslide by the roadside bund because of the previous night's rain. Probably, the burrow had been destroyed by the landslide and, when spotted, the female was in search of a new site to construct her burrow. Searching for other females was hampered by the lack of a thick layer of silk at the burrow entrance (confused for a lycosid spider burrow), which is characteristic of a theraphosid burrow. The burrows were $15-25 \mathrm{~mm}$ in diameter and 0.15-0.25 m deep. In May 2010, one empty eggsac was found in the burrow with the female; probably the eggsac was from the previous season. No eggsac was found in April-May. Mature males were observed from September to March.

\section{Neoheterophrictus sahyadri sp. nov.}

(Image 3-4, Figs. 4A-I, 5A-H, 6A-F, Table 3)

urn:Isid:zoobank.org:act:3742F690-386A-4C3E-BA7C-97378673A96D

\section{Type specimens}

Holotype: Female, 19.iv.2010, mixed forest, Between Nagoda and Joida, Uttara Kannada, Karnataka, India $\left(15.188028^{\circ} \mathrm{N} \& 74.490056^{\circ} \mathrm{E}, 584 \mathrm{~m}\right)$, coll. $\mathrm{M}$. Siliwal, N. Gupta, S. Chauhan, WILD-10-ARA-1008.

Allotype: Male, 24.i.2010, Kadra, Uttara Kannada, Karnataka, India $\left(14.91897^{\circ} \mathrm{N} \& 74.36071^{\circ} \mathrm{E}, 29 \mathrm{~m}\right)$, 


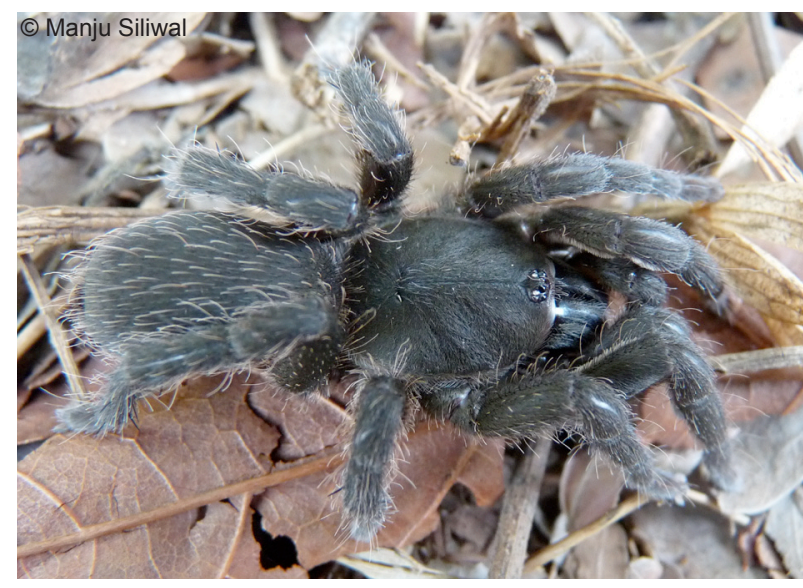

Image 3. Female of Neoheterophrictus sahyadri sp. nov. (Holotype, WILD-10-ARA-1008)

coll. S. Behara, M. Siliwal, Neha Gupta, WILD-10ARA-579.

Paratype: 1 female, 26.ix.2009, data same as allotype, coll. M. Siliwal, S. Behera, WILD-09ARA-418.

\section{Diagnosis}

Females of $N$. sahyadri sp. nov. differ from other species in spermathecae structure (Fig. 4I), two receptacles, each receptacle not very long and broad, constricted at apex, where 6-7 large contiguous lobes present(in $N$. crurofulvus sp. nov., receptacles relatively longer and gradually narrowing down towards apex and many, very small lobes); cephalothorax, chelicerae, legs and abdomen greenish-black in life (Image 3) (in $N$. crurofulvus sp. nov., legs, chelicerae, margins of carapace and ventral and lateral sides of abdomen coffee brown, rest black in life); tarsi of same colour as legs, blackish-brown (in $N$. crurofulvus sp. nov., legs uniformly coloured, coffee-brown).

Male of $N$. sahyadri sp. nov. differs by the presence of thick spine at base of primary tibial spur on retrolateral aspect (Fig. 6B); palp embolus gently curving retrolaterally towards tip; metatarsi and tarsi of all legs completely white (whereas in N. crurofulvus sp. nov. distal two-thirds of metatarsi and complete tarsi white), more brighter on anterior legs than posterior legs (Image 4); spider lighter in colour than male of $N$. crurofulvus sp. nov.

\section{Etymology}

The species name is a noun in apposition for Sahyadri, vernacular name for the Western Ghats.

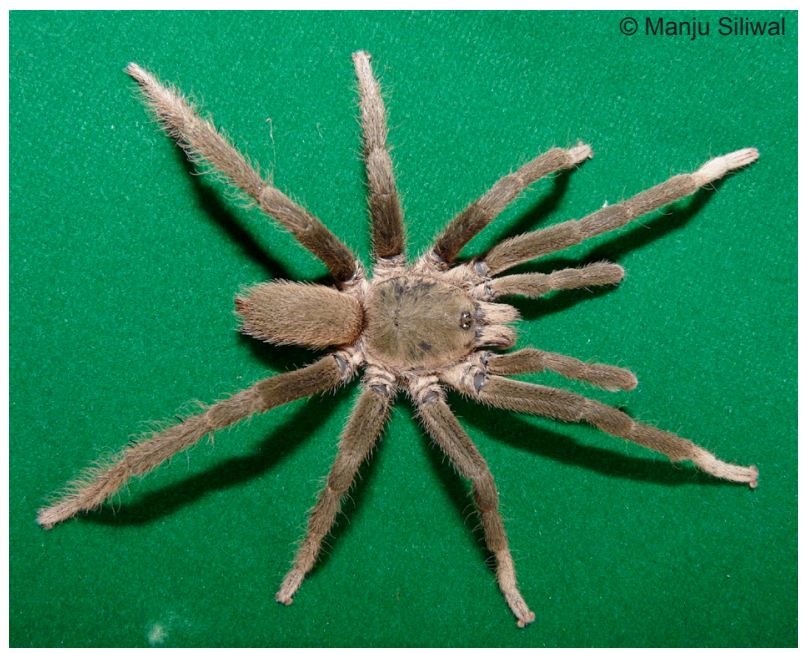

Image 4. Male of Neoheterophrictus sahyadri sp. nov. (Allotype, WILD-10-ARA-579)

\section{Description of female holotype (WILD-10- ARA-1008)}

Total length 22.78. Carapace 10.51 long, 7.91 wide, chelicerae 6.08 long. Abdomen 12.27 long, 6.80 wide. Spinnerets: PMS, 1.13 long, 0.29 wide, 0.46 apart; PLS, 1.45 basal, 1.08 middle, 1.10 apical, mid-width $0.78,0.71,0.51$ respectively, 3.63 total length.

Colour in life (Image 3): Carapace, chelicerae, legs and abdomen greenish-black, reflects greyish shade in light. Periphery of carapace, legs and abdomen covered with pallid long hairs with black bristles with orange red tips.

Carapace (Fig. 4A): Length to width ratio 1.30; reddish-brown; covered with strong mat of short greyish-brown hairs, more dense towards margins and concentrated along striae radiating from fovea, long curved light brown hairs with pallid tips at periphery. Bristles: 17 long on caput in anteromedially; 7 long and 14-16 short between anterior eyes; 9 long, 6 short between PME; 9 long, 8 short on clypeus edge. Mat of fine hair on anterior and posterior ocular area, fine grey hair between ALE-PLE. Fovea deep, slightly procurved. Two glabrous bands emerging from anteriorlateral sides of carapace on either side of caput broadens posteriorly and ends up before fovea. Caput not much higher than cephalic and thoracic region.

Eyes (Fig. 4B): Group occupies 0.30 of headwidth; ratio of group width to length 1.98. ALE clearly larger than rest, PME clearly smaller than PLE. Eye diameter: ALE, 0.41; AME, 0.26; PLE, 0.23; PME, 0.20 . Distance between eyes: AME-AME, 0.13; PME- 
Table 3. Neoheterophrictus sahyadri sp. nov., measurements of legs and palp of holotype (WILD-10-ARA-1008), paratype (WILD-10-ARA-579)

\begin{tabular}{|c|c|c|c|c|c|c|c|c|c|c|}
\hline & \multicolumn{2}{|c|}{ Leg I } & \multicolumn{2}{|c|}{ Leg II } & \multicolumn{2}{|c|}{ Leg III } & \multicolumn{2}{|c|}{ Leg IV } & \multicolumn{2}{|c|}{ Palp } \\
\hline & HT & PT & HT & PT & HT & PT & HT & PT & HT & PT \\
\hline Femur & 6.56 & 9.1 & 5.31 & 8.27 & 5.22 & 7.38 & 6.75 & 10.49 & 4.92 & 5.40 \\
\hline Patella & 4.36 & 5.05 & 3.88 & 4.25 & 3.68 & 3.71 & 3.84 & 4.40 & 3.38 & 3.34 \\
\hline Tibia & 4.98 & 7.79 & 3.83 & 5.62 & 3.39 & 5.01 & 5.41 & 8.10 & 3.35 & 4.36 \\
\hline Metatarsus & 2.48 & 6.37 & 3.23 & 6.03 & 4.38 & 6.74 & 6.28 & 10.5 & - & - \\
\hline Tarsus & 1.92 & 2.61 & 2.14 & 3.23 & 2.13 & 3.28 & 2.94 & 3.99 & 2.83 & 0.97 \\
\hline Total & 20.3 & 30.92 & 18.39 & 27.4 & 18.8 & 26.12 & 25.22 & 37.48 & 14.48 & 14.07 \\
\hline \multicolumn{11}{|l|}{ Midwidth } \\
\hline Femur & 1.79 & 2.03 & 1.55 & 2.10 & 1.96 & 2.15 & 1.63 & 1.84 & 1.47 & 1.19 \\
\hline Tibia & 1.92 & 1.52 & 1.38 & 1.34 & 1.54 & 1.45 & 1.74 & 1.45 & 1.54 & 1.29 \\
\hline
\end{tabular}
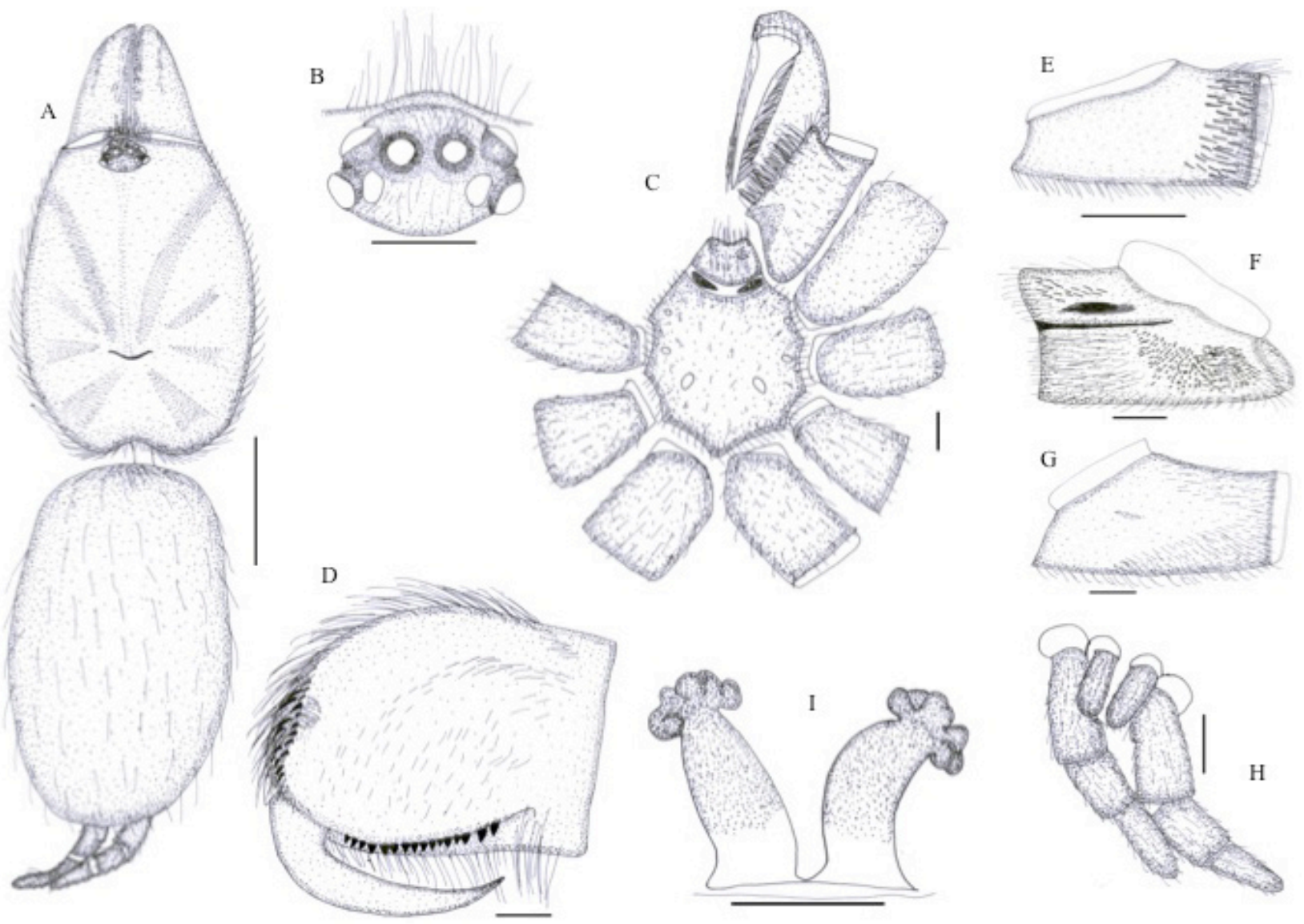

Figure 4. Neoheterophrictus sahyadri sp. nov., female (WILD-10-ARA-1008).

A - Carapace and abdomen dorsal view; B - Eye; C - Sternum, maxillae, labium, chelicerae; D - Chelicerae prolateral view; E - Maxillae, retrolateral view; F - Coxa I, prolateral view; G - Coxa I, retrolateral view; H - Spinnerets; I - Spermathecae. Scale $1.0 \mathrm{~mm}$ for B-I and scale $0.5 \mathrm{~mm}$ for $A$.

PLE, adjacent; AME-ALE, 0.02; PME-PME, 0.65. Ocular Quadrate, 0.74 long, 1.47 wide. MOQ: length, 0.63 ; front width, 0.66 ; back width, 1.09. Clypeus narrow.

Maxillae (Fig. 4C,E): 3.11 long in front, 4.47 long in back, 2.22 wide. Posterior edge near heel concave, anterior lobe distinct, serrula absent, long bristles present; posterior ventral edge straight. Cuspules: ca. 160 sparsely arranged in anterior corner in triangle region. Prolateral face, scattered short and long hair 
present, few short stiff hair above maxillary suture, setae and bristles absent. Retrolateral face reddishorange, glabrous in centre with thin short (stiff black bristles) spines on distal quarter, posterior and retroventral edge.

Labium (Fig. 4C): 1.27 long, 1.49 wide; ca 24 cuspules in band (in two groups) for one-fourth of length anteriorly; cuspules similar in size to those on maxillae. Basal groove shallow, distinct. Labiosternal groove convex. One pair of large sigilla present in labiosternal groove but not meeting in centre.

Chelicerae (Fig. 4D): Intercheliceral spines absent. Chelicerae lyra absent. Prolateral, not smooth, band with ridges sparsely covered with hairs running on curved chelicerae shape in just below dorso-prolateral face with 4-5 stiff bristles at base, a few scattered small hairs present on prolateral face; retrolateral faces glabrous, reddish-brown; 16 promarginal teeth , 28 basomesal teeth in 1-4 rows. Rastellum present, 21 short thick curved spines in 1-2 rows present on dorsoprolateral edge of chelicerae.

Sternum (Fig. 4C): 4.40 long, 4.08 wide. Almost round, high in centre, sloping gradually, covered with long and short black hair. Posterior angle short and blunt and not separating coxae IV. Posterior edge clearly seen. A few scattered small pallid hair covering base of sternum like mat, but not dense. 1-2 rows of long black bristles like hair present on margins posteriorly. Pedicle pallid, not seen properly.

Sigilla (Fig. 4C): three pairs, posterior sigilla, oval, 0.29 diameter, ca. 1.47 apart, 0.64 from margin; middle, oval, 0.18 diameter, 3.12 apart, 0.20 from margin; anterior, very small, round, marginal.

Legs: Formula 4132. All legs almost subequal in thickness, reddish-brown. Basifemoral thorns absent on all. Mat of short feathery hair (Image 3, resembling scopulae hair) present on prolateral side of distal half of coxae, trochanter to patella of leg I and on retrolateral side of distal half of coxae, trochanter to tibia of palp (not as dense as on leg I); also narrow band of feather hair present on prolateral side of femorae of palp. Mt III-IV 2.06 to 2.14 times longer than ta.

Spines: I: $\mathrm{mt}, \mathrm{v}=1$. II: ti, $\mathrm{v}=2$; $\mathrm{mt}, \mathrm{v}=4$. III: pa, $\mathrm{p}=1, \mathrm{ti}, \mathrm{p}=1, \mathrm{r}=1, \mathrm{v}=4 ; \mathrm{mt}, \mathrm{p}=\mathrm{r}=2, \mathrm{v}=6$. IV: ti, $\mathrm{p}=\mathrm{r}=2$, $\mathrm{v}=4 ; \mathrm{mt}, \mathrm{p}=\mathrm{r}=2, \mathrm{v}=6$. Palp: ti: $\mathrm{p}=1$. Spines on distal metatarsi: I, 1 ventral; II, 1ventral, 2 ventrolateral; IIIIV, 1ventral, 2 ventrolateral.

Trichobothria: Tarsi: I, 28 clavate, 11 long and
8 short filiform; II, 29 clavate, 10 long and 7 short filiform; III, 29 clavate, 8 long and 6 short filiform; IV, 24 clavate, 11 long and 6 short filiform; palp, 27 clavate, 6 long and 4 short filiform. Clavate on I-IV in distal three-quarters in two rows; filiforms only in basal three-quarters. Short epitrichobothrial hair field on tarsi as wide as clavates and uniform height for length but not very dense as seen in theraphosids.

Coxae (Figs. 4F-G): Coxal bases dorsally easily seen from above. I longest, about 1.33 times length of II; IV clearly widest, edge curves dorsally, rounded at interface. Coxae ventrally with short and long black hair, weak thorns present on prolateral faces of I-II and very much reduced on III-IV, sparsely distributed in basal one half portion on coxae I, one fourth basal on coxae II, very few on proventral basal edge; above suture thick blackish-brown long thick stiff setae along with brush of fine grey hair on leg I-II, on III-IV reduced to a few setae. I-IV ventrally covered with a mat of small grey hairs at base of coxae, intermixed with long and short black and pallid hair, all coxa sloping forward. Retrolateral setation: I-III with median narrow light thin brush of pallid hair in centre, IV glabrous.

Leg pilosity: Posterior legs more hairy than anterior legs. Femorae of all legs ventrally have pallid brush like long hair but not very dense. All legs covered with a mat of greyish-brown short hair. A number of long hairs extending well above base layer, I: fe, $\mathrm{p}=10$, $d=15, v=50 ; p a, d=8, p=2, v=10, r=12 ; t i, d=12, p=15$, $\mathrm{v}=14, \mathrm{r}=13 ; \mathrm{mt}, \mathrm{d}=6, \mathrm{p}=15, \mathrm{v}=8, \mathrm{r}=12 ; \mathrm{ta}, \mathrm{d}=\mathrm{p}=5, \mathrm{r}=4$. II: fe, $d=15, p=5, v=25, r=15 ; p a, d=r=4, p=2, v=7$; ti, $\mathrm{d}=12, \mathrm{p}=10, \mathrm{v}=21, \mathrm{r}=7$; $\mathrm{mt}, \mathrm{d}=10, \mathrm{p}=12, \mathrm{v}=16, \mathrm{r}=6$; ta, $d=6, p=18, r=12$. III: fe, $d=20, p=14, v=40, r=12 ; p a$, $\mathrm{d}=8, \mathrm{p}=5, \mathrm{v}=4, \mathrm{r}=3$; ti, $\mathrm{d}=10, \mathrm{p}=15, \mathrm{v}=25, \mathrm{r}=15 ; \mathrm{mt}$, $d=p=20, v=30, r=20 ;$ ta, $d=7, p=9, r=7$. IV: fe, $d=p=20$, $\mathrm{v}=35 ; \mathrm{pa}, \mathrm{d}=18, \mathrm{p}=10, \mathrm{v}=15, \mathrm{r}=25 ; \mathrm{ti}, \mathrm{d}=\mathrm{p}=20, \mathrm{v}=15$, $\mathrm{r}=25 ; \mathrm{mt}, \mathrm{d}=\mathrm{p}=25, \mathrm{v}=20, \mathrm{r}=30 ; \mathrm{ta}, \mathrm{d}=6, \mathrm{p}=25, \mathrm{r}=20$. Palp: fe, $d=, v=25 ; \mathrm{pa}, \mathrm{d}=, \mathrm{v}=4$; ti, $d=, \mathrm{p}=4, \mathrm{v}=14, \mathrm{r}=5$; ta, $\mathrm{d}=, \mathrm{p}=\mathrm{r}=8$.

Scopulae: Entire on all tarsi, divided with setae, division broader distally; ta I, divided centrally with band of 3-4 setae (distally 5-6 setae), ta II, divided with band of 5-6 setae (distally 8-9 setae), ta III, divided with band of 5-6 setae (distally 8-10 setae), ta IV, divided with band of 5-6 setae (distally 9-10 setae); palp ta divided with band of 4-5 setae (distally 6-8 setae). Metatarsi scopulae undivided and intermixed 


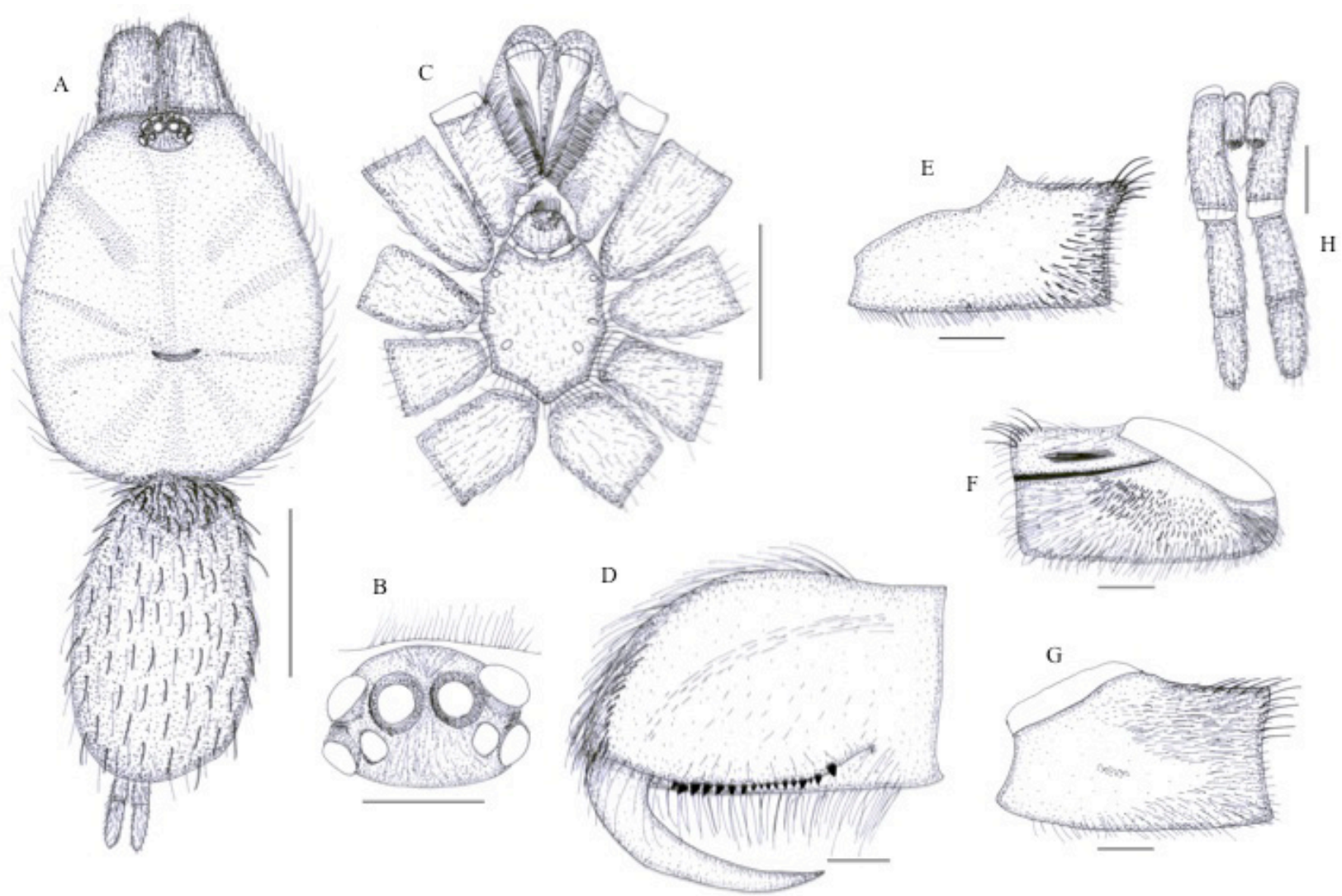

Figure 5. Neoheterophrictus sahyadri sp. nov., male (WILD-10-ARA-579).

A - Carapace and abdomen dorsal view; B - Eye; C - Sternum, maxillae, labium, chelicerae; D - Chelicerae prolateral view; E - Maxillae, retrolateral view; F - Coxa I, prolateral view; G - Coxa I, retrolateral view; H - Spinnerets. Scale 1.0mm for B, D-H and scale $0.5 \mathrm{~mm}$ for $\mathrm{A}, \mathrm{C}$.

with long black hair and bristles. No scopula on proventral tibiae.

Tarsal weakness: Not prominent.

Claws: Paired claws on leg I-IV without dentition and single bare claw on palp. Claw tufts well developed but not obscuring claws.

Abdomen pilosity (Image 3): Oval; cuticle not exposed dorsally and ventrally, covered with a thick mat of black-brown hair intermixed with long and short black hair, many pallid hairs.

Spinnerets (Fig. 4H): Two pairs, digitiform, yellowish with brown hairs.

Spermathecae (Fig. 4I): Two receptacles with multiple large lobes at apex. Each receptacle stout, broader (almost as wide as width of the cluster of lobes at apex) with constriction at apex, where a cluster of 6-7 large contiguous lobes (of different size) present; spermatheca appears like a tree with a stout trunk.
Description of allotype male (WILD-10-ARA-579)

Total length 19.27. Carapace 10.04 long, 8.78 wide, chelicerae 5.36 long. Abdomen 9.23 long, 4.51 wide. Spinnerets: PMS, 0.54 long, 0.33 wide, 0.21 apart; PLS, 1.05 basal, 1.37 middle, 1.30 apical, mid-width $0.35,0.49,0.35$ respectively, 3.72 total length.

Colour in life (Image 4): Carapace, greenish-brown with lighter margins. Legs and palp greenish-brown except for metatarsi of legs and tarsi of legs and palp white (brighter on anterior legs than posterior legs and palp); margins of carapace lighter. Chelicerae and dorsal side of coxae and trochanter creamish/pallid. Abdomen dorsal and ventral light brown.

Carapace (Fig. 5A): Length to width ratio 1.14; reddish-brown, lighter towards periphery; covered with a strong mat of short golden/pallid hairs, more dense towards margins and concentrated along striae radiating from fovea, long, curved brown with pallid tips hairs at periphery. Bristles: 6 long, many short anteromedially; 8 long, many short like brush of pallid 

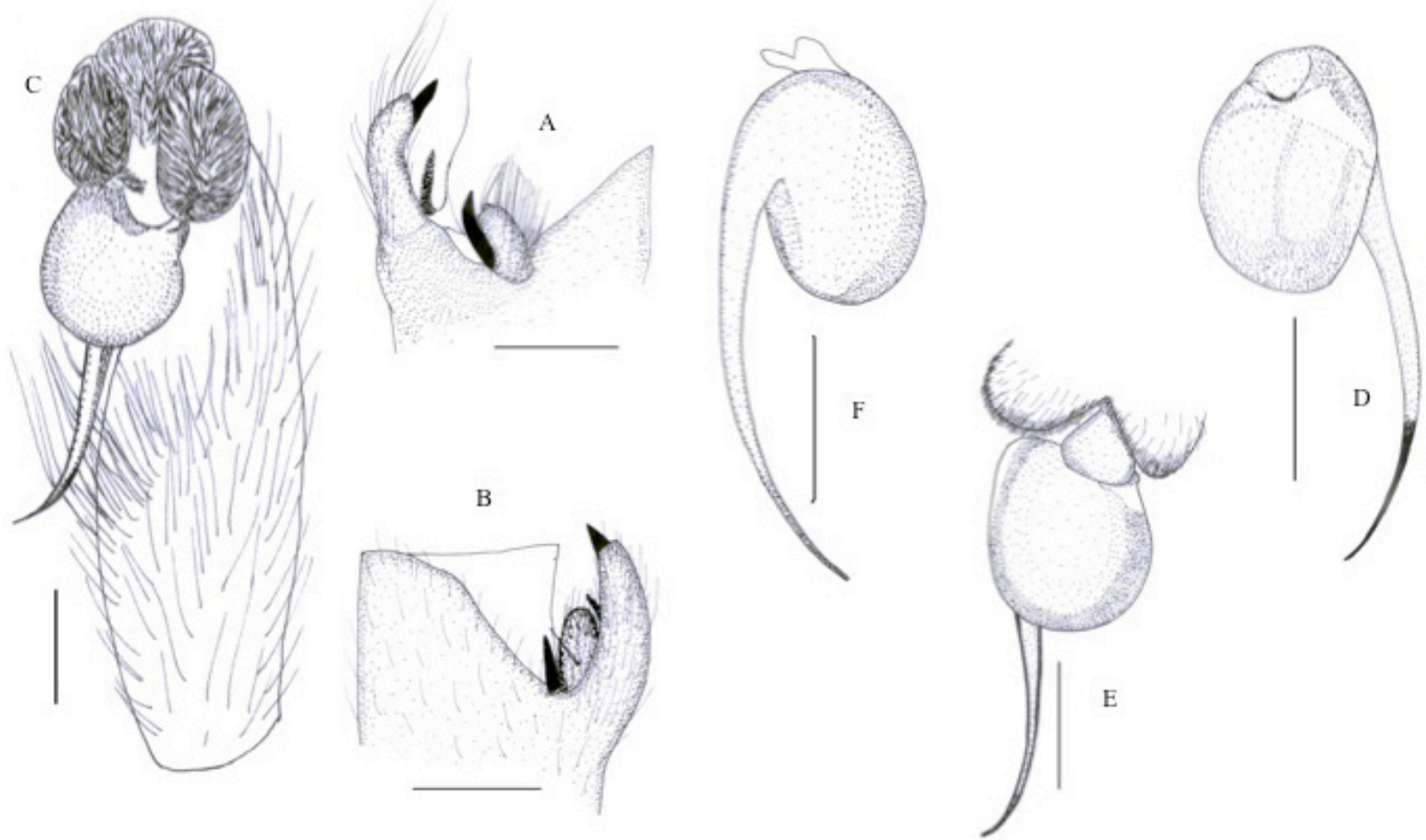

Figure 6. Neoheterophrictus sahyadri sp. nov., male (WILD-10-ARA-579).

A - Tibial spur, prolateral view; B - Tibial spur, retrolateral view; C - Tibia to Palp, retrolateral view; D - Palp, Prolateral view; E - Palp, ventral view; F - Palp, retrolateral view. Scale 1.0mm for A-F.

hairs between PME; 12 long, 11 short on clypeus edge. A mat of fine hair on anterior and posterior ocular area, fine golden hair between PLE-ALE, PME-PME, ALEALE. Fovea deep, slightly procurved. Two glabrous bands emerging from anteriorlateral sides of carapace, on either side of caput, broadens posteriorly and ends before fovea. Caput is not higher than cephalic and thoracic region.

Eyes (Fig. 5B): Group occupies 0.47 of headwidth; ratio of group width to length 2.09. ALE clearly larger than rest, PME smaller than rest. Eyes on ocular tubercle. Eye diameter: ALE, 0.31; AME, 0.29; PLE, 0.27; PME, 0.26. Distance between eyes: AME-AME, 0.06; PME-PLE, adjacent; AME-ALE, 0.04; PME-PME, 0.47. Ocular Quadrate, 0.65 long, 1.36 wide. MOQ: length, 0.54 ; front width, 0.59 ; back width, 0.98; difference between back and front width, 0.39 . Clypeus very narrow.

Maxillae (Fig. 5C,E): 2.67 long in front, 3.59 long in back, 1.73 wide. Posterior edge near heel concave, anterior lobe distinct, serrula absent, long bristles present; posterior ventral edge straight. Cuspules: ca.140 in anterior corner in triangle region. Prolateral face, scattered short and long hair present, a few short stiff hair above maxillary suture with setae and bristles absent. Retrolateral face reddish-orange, glabrous in centre with thin short (stiff black bristles) spines on distal quarter, posterior and retroventral edge.

Labium (Fig. 5C): 1.19 long, 1.51 wide; ca. 70 cuspules in band for quarter of length anteriorly; cuspules similar in size to those on maxillae. Basal groove shallow, distinct. Labiosternal groove convex. One pair of large sigilla present in labiosternal groove, not touching at the centre.

Chelicerae (Fig. 5D): 5.53 long, intercheliceral spines absent. Chelicerae lyra absent. Prolateral, not smooth, band with strong ridges (more prominent on mid band), sparsely covered with hairs running in curved chelicerae shape just below dorso-prolateral face with 3-4 stiff bristles at base, and a few scattered small hairs present on prolateral face; retrolateral faces glabrous, reddish-brown; 17 promarginal, 41 basomesal teeth in 1-4 rows. Rastellum not very prominent, covered with 17 stiff bristle-like spines in 2-3 rows on anterior dorsoprolateral edge of chelicerae.

Sternum (Fig. 5C): 4.63 long, 3.80 wide. Oval, high in centre, sloping gradually, covered with long 
and short brown hair. Posterior angle short and blunt and not separating coxae IV. Posterior edge clearly seen. A few small pallid hair covering base of sternum like a mat but not dense. A single row of long brown bristle-like hair present on margins in posterior half. Pedicle pallid, not seen properly.

Sigilla (Fig. 5C): three pairs, posterior sigilla, oval, 0.39 diameter, ca. 1.92 apart, 0.42 distance from margin; median sigilla, oval, 0.23 diameter, 2.40 apart, 0.13 from margin; anterior, very small, round, marginal.

Legs (Figs. 6A-B): Formula 4123. Reddish-brown, covered with a mat of grey hair intermixed with hairs and bristles. All legs almost subequal in thickness. Basifemoral thorns absent on all. A mat of short feather hair (Image 4, resembling scopulae hair) present on prolateral side of distal half of coxae, trochanter to basal half of patella of leg I and on retrolateral side of distal half of coxae, trochanter to tibia of palp (not as dense as on leg I). Mt IV 2.60 times longer than ta IV, rest 1.90 to 2.40 times longer than ta. Tibial apophysis consists of two spurs ventrally, primary spur on ventro-retrolateral, long, slightly swollen at apex with prominent spine at tip, at base of primary spur on retrolateral face long thick straight spine; secondary spur on ventro-prolateral aspect of primary spur, rounded at apex with numerous bristles, hairs and a few tubercles on the inner side of it, long curved spine emerge at base of secondary spur, covering spur on its retrolateral aspect. No granules or spines present between two spurs.

Spines: I: ti, $v=2$ spurs, each with pointed spine, $\mathrm{r}=1 ; \mathrm{mt}, \mathrm{v}=1$. II: ti, $\mathrm{v}=3, \mathrm{r}=1 ; \mathrm{mt}, \mathrm{p}=1, \mathrm{v}=2$. III: ti, $\mathrm{p}=1$, $\mathrm{r}=2, \mathrm{v}=4 ; \mathrm{mt}, \mathrm{p}=\mathrm{r}=2, \mathrm{v}=7$. IV: ti, $\mathrm{p}=1, \mathrm{r}=2, \mathrm{v}=4 ; \mathrm{mt}$, $\mathrm{p}=3, \mathrm{r}=2, \mathrm{v}=9$. Spines on distal metatarsi: I, 1 ventral; II, 2 ventrolateral; III, 1 ventral, 2 ventrolateral, IV, 1 ventral, 2 ventrolateral.

Trichobothria: ta I, 34 clavate, 10 long and 6 short filiform; ta II, 30+broken clavate, 12 long and 8 short filiform in 2 rows for length; ta III, 22+broken clavate, 8 long and 6 short filiform; ta IV, 18+broken clavate, 10 long and 7 short filiform; palp, 26 clavate, 5 long and 4 short filiform. Clavate on I-IV in distal threequarters in two bands; filiforms for length. Short epitrichobothrial hair field on all legs as wide as clavates and uniform height for length.

Coxae (Fig. 5F-G): Coxal bases dorsally easily seen from above. I longest, about 1.30 times longer than
II; IV clearly widest and basally with anterior corner distinct, edge curves dorsally, rounded at interface. I-IV ventrally covered with a mat of small pallid hairs intermixed with long and short black and pallid hair. Weak thorns present on prolateral faces of I-II but not as dense as in female and very much reduced on III, absent on IV, sparsely distributed in basal half of coxae I, basal quarter of coxae II, very few on proventral basal edge; above suture thick blackish-brown long thick stiff setae along with brush of fine grey hair on I, reduced on II, only a few setae on III-IV. I-III sloping forward and IV backward. Retrolateral setation: I-III with median narrow light brush of pallid hair, IV glabrous.

Leg pilosity: All legs not very hairy, III-IV relatively more hairy than I-II. All legs covered with a thick mat of pallid short hairs. Number of long hairs extending well above base layer, $\mathrm{I}$ : fe $\mathrm{d}=10, \mathrm{v}=30$; pa, $\mathrm{p}=2, \mathrm{~d}=6$; ti, $\mathrm{p}=7, \mathrm{~d}=15, \mathrm{r}=10, \mathrm{v}=12 ; \mathrm{mt}, \mathrm{p}=2+$ broken, $\mathrm{d}=15, \mathrm{v}=12, \mathrm{r}=4+$ broken; ta, $\mathrm{d}=10, \mathrm{p}=8, \mathrm{r}=10$, v=4. II: fe $d=10, r=5, v=50 ; p a, d=r=8, p=3, v=5 ; t i, d=15, p=5$, $\mathrm{r}=12, \mathrm{v}=25 ; \mathrm{mt}, \mathrm{d}=20, \mathrm{p}=9, \mathrm{r}=12, \mathrm{v}=16$; ta, $\mathrm{d}=12, \mathrm{p}=9$, $\mathrm{r}=12, \mathrm{v}=4$. III: fe, $\mathrm{d}=8, \mathrm{p}=10, \mathrm{r}=25, \mathrm{v}=30$; $\mathrm{pa}, \mathrm{d}=\mathrm{r}=4$, $\mathrm{p}=7, \mathrm{v}=10 ; \mathrm{ti}, \mathrm{d}=9, \mathrm{r}=6, \mathrm{p}=8, \mathrm{v}=20 ; \mathrm{mt}, \mathrm{d}=35, \mathrm{p}=17$, $\mathrm{v}=25, \mathrm{r}=15$; ta, $\mathrm{d}=10, \mathrm{p}=12, \mathrm{r}=15$. IV: fe, $\mathrm{d}=8, \mathrm{p}=10$, $\mathrm{v}=30, \mathrm{r}=5$; $\mathrm{pa}, \mathrm{p}=8, \mathrm{r}=4, \mathrm{v}=5$; ti, $\mathrm{d}=12, \mathrm{p}=15, \mathrm{v}=25$, $\mathrm{r}=20 ; \mathrm{mt}, \mathrm{d}=45, \mathrm{p}=25, \mathrm{r}=\mathrm{v}=35$; ta, $\mathrm{d}=7, \mathrm{p}=16, \mathrm{r}=20$.

Scopulae: Entire on all tarsi, intermixed with hair and divided with hair on tarsi I-III and tarsi IV divided with brown pale-tipped setae, division broader distally; ta I-II, divided with single row of hairs (distal bunch of setae like hairs at base of claw tufts; III, divided with a band of 3-4 setae (distal with a bunch of setae), ta IV, divided with band of 4-5 setae (distally 10-12 setae). Mt I, distal three-quarters; met II, distal half; mt III-IV, distal quarter, scanty. Metatarsi scopulae intermixed with long black hair, bristles and spines. No scopula on proventral tibiae.

Tarsal weakness: not prominent.

Claws: Paired claws on leg I-IV without dentition and single bare claw on palp. Claw tufts well developed but not obscuring claws.

Abdomen pilosity (Image 4): Dorsally, coffeebrown with greyish shade posteriorly, ventrally, greenish-brown. Cuticle not exposed dorsally and ventrally; dorsally covered with a thick mat of pallid hair intermixed with brown pale-tipped bristles; ventrally and ventrolateral uniformly greenish-brown, 
a thick mat of fine pallid hair, intermixed uniformly with long pallid hair.

Spinnerets (Fig. 5H): Two pairs, digitiform, yellowish covered with pallid hairs.

Palp (Figs. 6C-F): Tarsi divided distally but not deep. Bulb large and twisted on cymbium with long embolus. Embolus emerges from posterioventral area of the tegulum, takes a $180^{\circ}$ bend and gradually tapers towards tip, diverting the retrolateral side of the bulb.

\section{Natural History}

Male and females of the species were found in mixed forest and semievergreen patches or moist areas of forest under decaying log or rocks with 60 $70 \%$ of canopy cover, $30-80 \%$ ground cover (based on season) and 0-20\% rock cover. No male was found in the burrow. Females were found in shallow holes/burrows (maximum $30 \mathrm{~cm}$ deep) below rock or decaying log. Females were found using burrows for hiding when log or rock was disturbed, otherwise found resting below the substrate. In the resting place they had prepared a small border with mud. Habitat information is similar to $N$. crurofulvus sp. nov.

\section{Neoheterophrictus uttarakannada sp. nov.} (Image 5, Figs. 7A-H, Table 4)

urn:Isid:zoobank.org:act:745FA172-9CDB-4873-895C-30F20E1EFF4D

\section{Type specimens}

Holotype: Female, 14.iv.2010, Anshi National Park, Uttara Kannada, Karnataka, India $\left(15.008^{\circ} \mathrm{N} \&\right.$ $\left.74.384472^{\circ} \mathrm{E}, 538 \mathrm{~m}\right)$, coll. M. Siliwal, N. Gupta and S. Chauhan, WILD-10-ARA-923.

Paratype: 1 female, 13.iii.2010, mixed forest, between Nagoda and Joida, behind agriculture fields, Uttara Kannada, Karnataka, India $\left(15.191972^{\circ} \mathrm{N}\right.$ \& 74.488611 ${ }^{\circ}$ E, 581m), coll. M. Siliwal, N. Gupta, S. Behera, K. Ramesh, WILD-10-ARA-672.

\section{Diagnosis}

Female of the new species differs from other species in spermathecae structure (Fig. $7 \mathrm{H}$ ), two receptacles, each receptacle relatively short and broader at base, gradually narrows towards apex, where 6-7 large contiguous lobes (of varying size) present (in $N$. crurofulvus sp. nov., receptacles relatively longer and gradually narrowing down towards apex with many very small lobes at apex; in $N$. sahyadri sp. nov.,

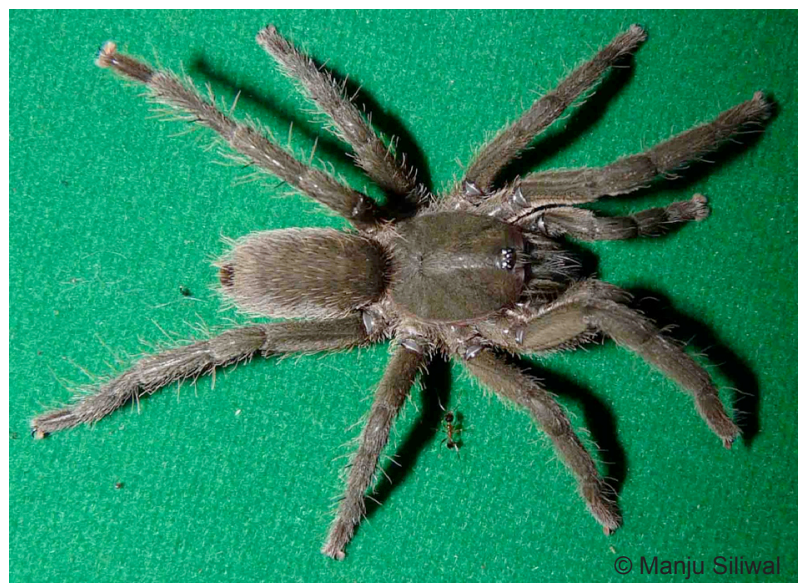

Image 5. Female of Neoheterophrictus uttarakannada sp. nov. (Holotype, WILD-10-ARA-923)

receptacles relatively short, broad, uniform width with constriction at apex, where 6-7 large contiguous lobes present); $\mathrm{mt}$ and ta I-II paler colour (yellowishorange) and less hair than rest of the legs parts (in $N$. crurofulvus sp. nov. and $N$. sahyadri sp. nov. all legs of uniform colour). Male unknown.

\section{Etymology}

The species name is noun in apposition for the district name Uttara Kannada (North Canara District), from where the type specimens were collected.

\section{Description of holotype female (WILD-10- ARA-923)}

Total length 18.30. Carapace 8.56 long, 6.72 wide, chelicerae 5.20 long. Abdomen 9.74 long, 5.40 wide. Spinnerets: PMS, 0.83 long, 0.24 wide, 0.32 apart; PLS, 1.52 basal, 1.08 middle, 1.27 apical, midwidth $0.67,0.65,0.52$ respectively, 3.87 total length. Morphometry of legs and palp in Table 4.

Colour in life (Image 5): Carapace, chelicerae, legs and abdomen greenish-brown, reflects brownish shade in light. The periphery of carapace, legs and abdomen covered with pallid long hairs and black bristles with orange red tips.

Carapace (Fig. 7A): Length to width ratio 1.30; reddish-brown; covered with a strong mat of short black hairs, more dense towards margins and concentrated along striae radiating from fovea, with long curved light brown hairs at periphery. Bristles: 14 long on caput in mid-dorsal line; 7 long and 14-16 short anteromedially; 9 long, 5 short between PME; 

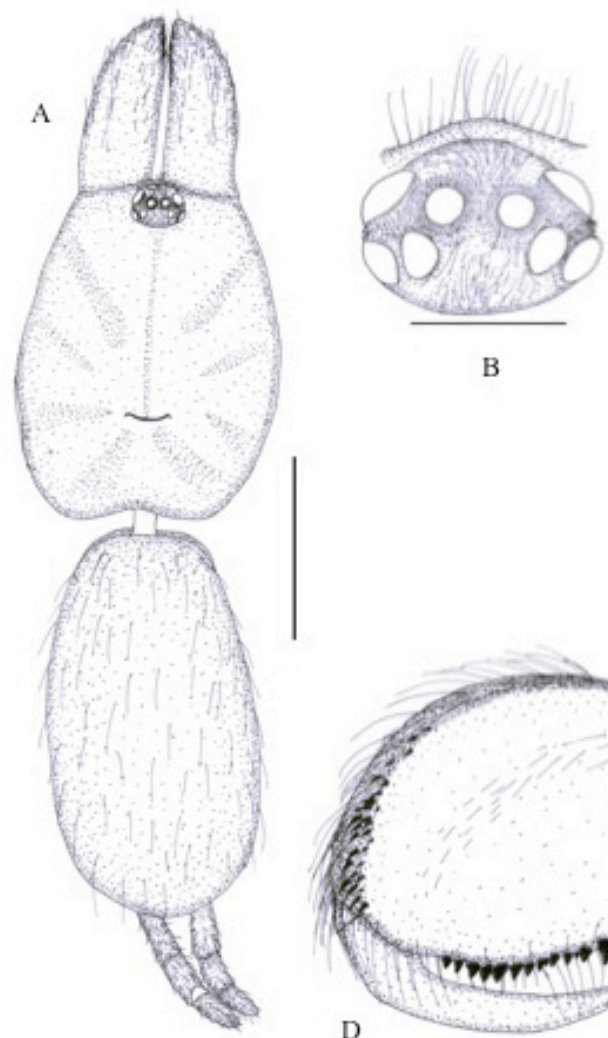

B

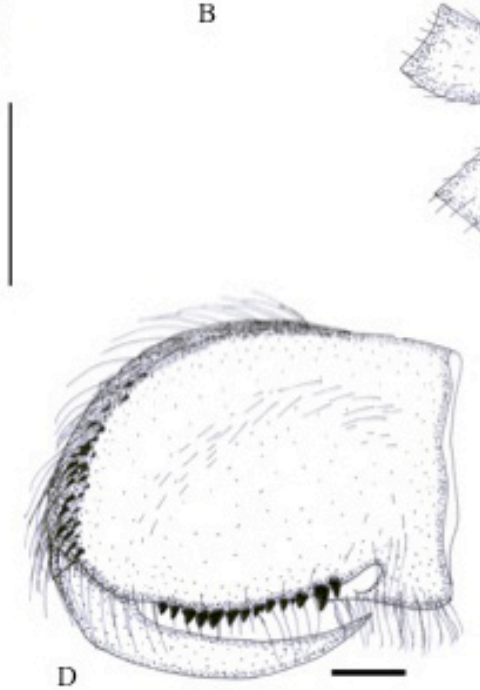

D
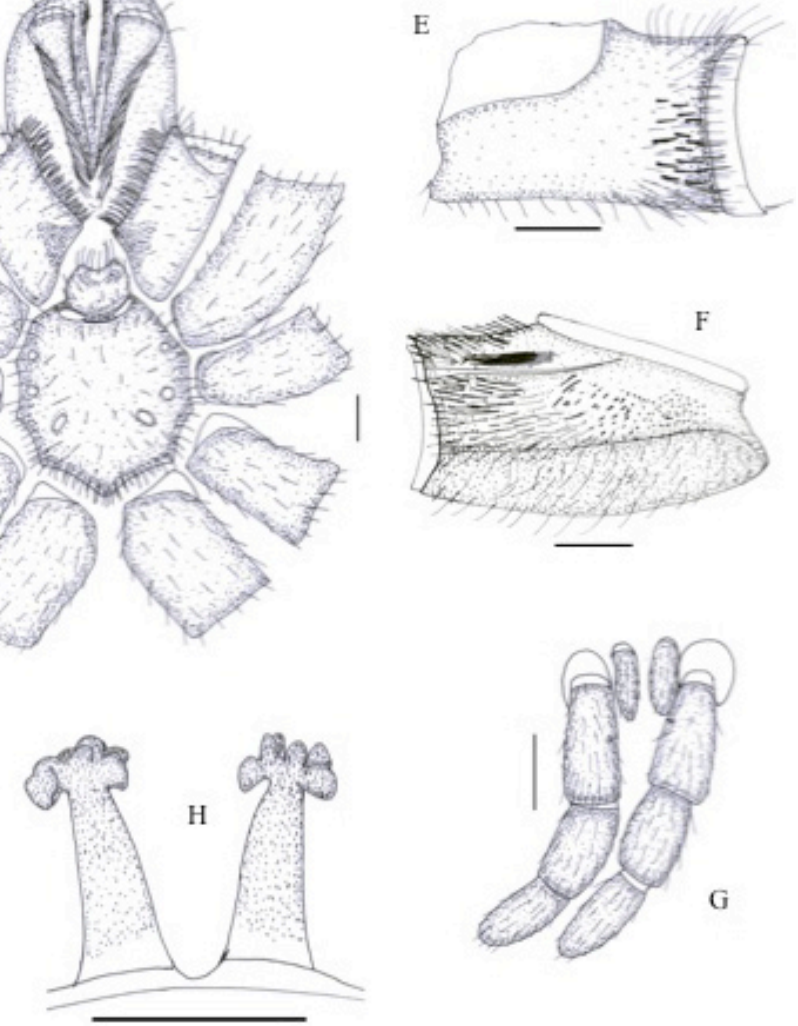

Figure 7. Neoheterophrictus uttarakannada sp. nov., female (WILD-10-ARA-923).

A - Carapace and abdomen dorsal view; B - Eye; C - Sternum, maxillae, labium, chelicerae; D - Chelicerae prolateral view; E - Maxillae, retrolateral view; F - Coxa I, prolateral view; G - Spinnerets; H - Spermathecae. Scale 1.0mm for B-H and scale $0.5 \mathrm{~mm}$ for $\mathrm{A}$.

1 long, 7 short on clypeus edge. A mat of fine hair on anterior and posterior ocular area, fine golden hair at base of PLE. Fovea deep, slightly procurved. Two glabrous bands emerging from anteriorlateral sides of carapace, on either side of caput, broadens posteriorly and ends up much before fovea. Caput is not much higher than cephalic and thoracic region.

Eyes (Fig. 7B): Group occupies 0.29 of head-width; ratio of group width to length 1.79. ALE clearly larger than rest, PME clearly slightly smaller than PLE. Eye diameter: ALE, 0.36; AME, 0.26; PLE, 0.25; PME, 0.23. Distance between eyes: AME-AME, 0.14; PME-PLE, adjacent; AME-ALE, 0.03; PME-PME, 0.44. Ocular Quadrate, 0.69 long, 1.24 wide. MOQ: length, 0.57; front width, 0.58; back width, 0.76. Clypeus narrow.

Maxillae (Fig. 7C,E): 2.48 long in front, 3.36 long in back, 1.75 wide. Posterior edge near heel concave, anterior lobe distinct, serrula absent, long bristles present; posterior ventral edge straight. Cuspules: ca. 200 arranged in anterior corner in triangle region.
Prolateral face, scattered short and long hairs present, a few short stiff hairs above maxillary suture, setae and bristles absent. Retrolateral face reddish-orange, glabrous in centre with thin short (stiff black bristles) spines on distal quarter, posterior and retroventral edge.

Labium (Fig. 7C): 0.94 long, 1.14 wide; ca $37+$ broken cuspules in band for quarter of length anteriorly; cuspules similar in size to those on maxillae. Basal groove shallow, distinct. Labiosternal groove convex. One pair of large sternal sigilla present in labiosternal groove but not meeting in centre.

Chelicerae (Fig. 7D): Intercheliceral spines absent. Chelicerae lyra absent. Prolateral surface, not smooth, band with ridges sparsely covered with hairs running on curved chelicerae shape just below dorso-prolateral face with 3-4 stiff bristles at base, a few scattered small hairs present on prolateral face; retrolateral faces glabrous, reddish-brown; 15 promarginal teeth, 38 basomesal teeth in 1-4 rows. Rastellum present, 22 short thick curved spines in 2 rows present on 
Table 4. Neoheterophrictus uttarakannada sp. nov., measurements of legs and palp of holotype (WILD-10-ARA-923), paratype (WILD-10-ARA-672)

\begin{tabular}{|c|c|c|c|c|c|c|c|c|c|c|}
\hline & Leg I & & Leg II & & Leg III & & Leg IV & & Palp & \\
\hline & HT & PT & HT & PT & HT & PT & HT & PT & HT & PT \\
\hline Femur & 5.74 & 5.66 & 4.73 & 4.47 & 4.45 & 4.36 & 6.4 & 5.64 & 4.34 & 3.83 \\
\hline Patella & 3.84 & 3.62 & 3.11 & 2.78 & 2.82 & 2.89 & 3.43 & 3.34 & 2.86 & 2.53 \\
\hline Tibia & 4.42 & 4.09 & 2.53 & 3.27 & 2.38 & 3.37 & 4.44 & 4.95 & 2.70 & 2.58 \\
\hline Metatarsus & 2.82 & 2.31 & 2.70 & 2.62 & 3.85 & 3.28 & 5.59 & 5.22 & - & - \\
\hline Tarsus & 1.83 & 2.09 & 1.87 & 2.19 & 2.19 & 2.43 & 2.51 & 3.22 & 2.23 & 2.51 \\
\hline Total & 18.65 & 17.77 & 14.94 & 15.33 & 15.69 & 16.33 & 22.37 & 22.37 & 12.13 & 11.45 \\
\hline \multicolumn{11}{|l|}{ Midwidth } \\
\hline Femur & 1.79 & 1.38 & 1.58 & 1.11 & 1.75 & 1.33 & 1.46 & 1.22 & 1.15 & 0.84 \\
\hline Tibia & 1.43 & 1.29 & 1.30 & 1.06 & 1.35 & 1.19 & 1.38 & 1.30 & 1.25 & 0.99 \\
\hline
\end{tabular}

dorsoprolateral edge of chelicerae.

Sternum (Fig. 7C): 3.81 long, 3.28 wide. Almost round, high in centre, sloping gradually, covered with long and short black hair. Posterior angle short and blunt and not separating coxae IV. Posterior edge clearly seen. A few scattered small pallid hairs covering base of sternum like a mat but not dense and not covering sternum. A single row of long black bristle-like hairs present on margins posteriorly. Pedicle pallid, not seen properly.

Sigilla (Fig. 7A): three pairs, posterior sigilla, oval, 0.33 diameter, ca. 1.39 apart, 0.42 from margin; middle, oval, 0.11 diameter, 2.95 apart, 0.06 from margin; anterior, very small, round, marginal.

Legs: Formula 4132. All legs almost subequal in thickness, reddish-brown. Basifemoral thorns absent on all. A mat of short feather hair (Image 5, resembling scopulae hair) present on prolateral side of distal half of coxae, trochanter to patella of leg I and on retrolateral side of distal half of coxae, trochanter to tibia of palp (not as dense as on leg I). Mt IV 2.23 times longer than ta IV; $\mathrm{mt}$ III 1.75 times longer than ta III; rest 1.40-1.50 times longer than ta.

Spines: I: ti, $\mathrm{p}=1 ; \mathrm{mt}, \mathrm{v}=1$. II: ti, $\mathrm{p}=2, \mathrm{r}=1 ; \mathrm{mt}, \mathrm{p}=1$, $\mathrm{r}=1, \mathrm{v}=2$. III: $\mathrm{pa}, \mathrm{p}=1, \mathrm{ti}, \mathrm{p}=\mathrm{r}=2, \mathrm{v}=1 ; \mathrm{mt}, \mathrm{p}=4, \mathrm{r}=3$, $\mathrm{v}=2$. IV: ti, $\mathrm{p}=3, \mathrm{r}=4, \mathrm{v}=1 ; \mathrm{mt}, \mathrm{p}=5, \mathrm{r}=3, \mathrm{v}=2$. Palp: ti: $p=1, r=1$. Spines on distal metatarsi: I, 1 ventral, 1 ventrolateral; II, 1 ventral, 2ventrolateral; III, 1ventral, 2ventrolateral; IV, 1ventral, 2ventrolateral.

Trichobothria: Tarsi: I, 26 clavate, 10 long and 8 short filiform; II, 24 clavate, 10 long and 6 short filiform; III, 23 clavate, 10 long and 6 short filiform; IV, 22-26 clavate, 10 long and 6 short filiform; palp,
26 clavate, 6 long and 4 short filiform. Clavate on I-IV in distal three-quarters in two rows; filiforms only in basal three-quarters. Short epitrichobothrial hair field on tarsi as wide as clavates and uniform height for length but not very dense.

Coxae (Fig. 7F): Coxal bases dorsally easily seen from above. I longest, about 1.33 times length of II; IV clearly widest and basally with anterior corner indistinct, edge curves dorsally, rounded at interface. Coxae ventrally with short and long black hair, weak thorns present on prolateral faces of I-II and very much reduced on III, absent on IV, sparsely distributed in basal half of coxae I, basal quarter on coxae II, very few on proventral basal edge; above suture thick blackishbrown long thick stiff setae along with a brush of fine grey hair on I, reduced on II, only few setae on III-IV. I-IV ventrally covered with golden brown mat of small hairs at base of coxae, long and short black and pallid hair, all coxa sloping forward. Retrolateral setation: I-III with median narrow light thin brush of pallid hair in centre, IV glabrous.

Leg pilosity (Image 5): Leg III-IV, tibia to tarsi covered with long hairs. Femorae of all legs ventrally have pallid brush like long hair. All legs covered with a mat of greenish-brown short hairs. A number of long hairs extending well above base layer, $\mathrm{I}$ : fe, $\mathrm{d}=7, \mathrm{v}=24$; pa, $d=10, p=2, v=10, r=8 ; t i, d=14, p=r=6 v=20 ; m t$, $\mathrm{d}=12, \mathrm{p}=4, \mathrm{v}=7, \mathrm{r}=2$; ta, $\mathrm{d}=10, \mathrm{p}=5, \mathrm{r}=5$. II: fe, $\mathrm{d}=8$, $p=2, v=16, r=18 ; p a, d=9, p=4, v=8, r=7 ; t i, d=15, p=7$, $\mathrm{v}=15, \mathrm{r}=7 ; \mathrm{mt}, \mathrm{d}=10, \mathrm{p}=7, \mathrm{v}=14, \mathrm{r}=6$; ta, $\mathrm{d}=12, \mathrm{p}=\mathrm{r}=6$. III: fe, $d=17, p=7, v=24, r=5$; pa, $d=p=5, v=4, r=9$; ti, $\mathrm{d}=6, \mathrm{p}=8, \mathrm{v}=12, \mathrm{r}=13 ; \mathrm{mt}, \mathrm{d}=13, \mathrm{p}=20, \mathrm{v}=10, \mathrm{r}=13$; ta, $d=8, p=9, r=12$. IV: fe, $d=8, p=4, v=30, r=2 ; p a, d=7$, 
$\mathrm{p}=\mathrm{v}=6, \mathrm{r}=10 ; \mathrm{ti}, \mathrm{d}=10, \mathrm{p}=\mathrm{r}=\mathrm{v}=12 ; \mathrm{mt}, \mathrm{d}=13, \mathrm{p}=\mathrm{v}=20$, $\mathrm{r}=25$; ta, $\mathrm{d}=7, \mathrm{p}=10, \mathrm{r}=14$. Palp: fe, $\mathrm{d}=7, \mathrm{v}=14$; $\mathrm{pa}$, $\mathrm{d}=10, \mathrm{v}=4$; ti, $\mathrm{d}=10, \mathrm{p}=5, \mathrm{v}=10, \mathrm{r}=2 ;$ ta, $\mathrm{d}=12, \mathrm{p}=4$, $\mathrm{r}=2$.

Scopulae: Entire on all tarsi, intermixed with hair and divided with setae, division broader distally; ta I, divided centrally with band of 4-5 setae (distally 8-9 setae), ta II, divided with band of 4-5 setae (distally 12-14 setae), ta III, divided with band of 4-5 setae (distally 14-16 setae), ta IV, divided with band of 4-5 setae (distally 16-18 setae); palp ta divided with band of 4-5 setae (distally 6-8 setae). Metatarsi scopulae undivided, intermixed with long black hair and bristles. No scopula on proventral tibiae.

Tarsal weakness: Not prominent.

Claws: Paired claws on leg I-IV without dentition and single bare claw on palp. Claw tufts well developed but not obscuring claws.

Abdomen pilosity (Image 5): Oval; cuticle not exposed dorsally and ventrally; dorsally covered with a thick mat of greyish-black hair intermixed with long and short black hairs, many pallid hairs; ventrally and ventrolateral a uniformly greyish-brown, thick mat of fine greyish-brown hair, intermixed uniformly with long pallid hairs.

Spinnerets (Fig. 7G): Two pairs, digitiform, yellowish with brown hairs.

Spermathecae (Fig. 7H): Two receptacles with multiple large lobes at apex, appears like sketch of tree. Each receptacle relatively short and broader at base, gradually narrows towards apex (like tree trunk), where 6-7 large contiguous lobes (of varying sizes) present.

\section{Variations in paratype}

Total length: 18.79. Carapace: 7.28 long, 5.96 wide. Ocular group: 0.52 long, 1.09 wide. MOQ: 0.47 long, front width 0.60 , back width 0.77 . Labium 1.24 long, 1.48 wide, 27 cuspules. Sternum: 3.97 long, 3.07 wide. Maxillae: 2.68 long in front, 3.34 long in back, 1.95 wide; cuspules ca.200. Abdomen: 8.37 long, 4.35 wide.

\section{Natural History}

It is similar to $N$. sahyadri sp. nov., females were found below small rocks and had shallow burrows for temporary hideouts.

\section{DISCUSSION}

Guadanucci (2011) transferred Heterophrictus to the subfamily Eumenophorinae based on presence of plumose stridulatory setae above suture of coxae I. However, it is not stated whether this character is present only on coxae I or coxae I and II or all coxae. As per characters of Eumenophorinae, paddle and spike setae or just spike setae are present on coxae I-II (Smith 1990). Moreover, none of the members of the Eumenophorinae have been reported to have a rastellum on the chelicerae. Rastellum is only reported in Euphrictus Hirst, 1908 (Selenogyrinae). It is very likely that a rastellum is present in many described theraphosid genera and which would have been missed out by pioneer arachnologists. A complete revision for theraphosid genera is urgently needed. As the new genus is phylogenetically related to Heterophrictus, we also place Neoheterophrictus gen. nov. in the subfamily Eumernophorinae.

An interesting character observed in all the specimens (both sexes) of Neoheterophrictus gen. nov. is the presence of large feathery hair (appearing like scopulae from lateral view) on prolateral of distal half of coxae, trochanter to patella of leg I and on retrolateral of distal half of coxae, trochanter to tibia and a band on prolateral femorae of palp. It is very prominent from the dorsal view in preserved and spider in life. This character has been previously reported in the Australian genus Xamiatus Raven, 1981 of the family Nemesiidae; African theraphosid genera Encyocratella Strand, 1907 (Stromatopelminae) and Pelinobius Karsch, 1885 (Eumenophorinae) (Raven 1981; Gallon 2003, 2005, 2010). According to Gallon (2003), these hairs are used with a stridulatory function.

With the additional information on Plesiophrictus and Heterophrictus by Guadanucci (2011), the photographs of type specimens of Plesiophrictus deposited at Zoological Survey of India, Kolkata were re-examined and comments on a few Plesiophrictus sp. are provided here. However, the validation for all Indian Plesiophrictus is not provided here due to lack of information on important generic characters and it will be done after re-examination of the type specimens in different museums.

The type specimen of Plesiophrictus bhori Gravely, 1915 (Type, ZSIK 2218/17) from Parambikulam, Cochin State (now Kerala) and P. mahabaleshwari 


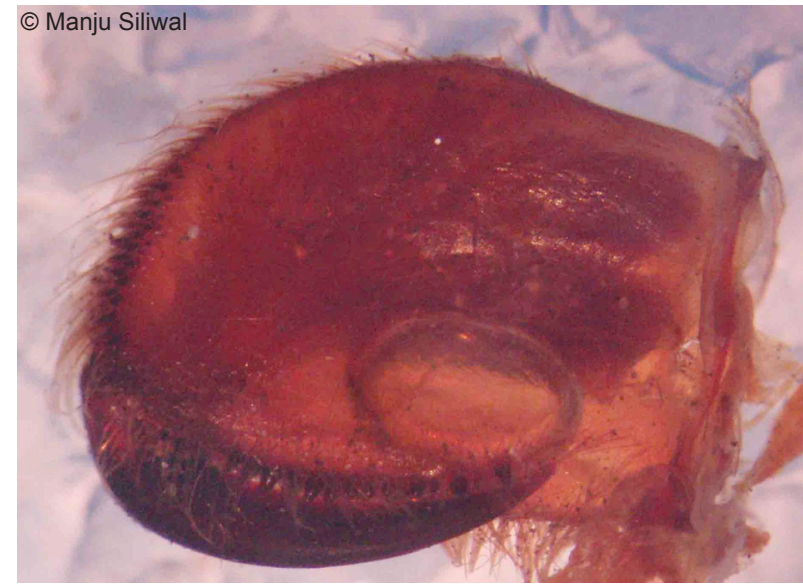

Image 6. Plesiophrictus bhori, chelicerae, prolateral view

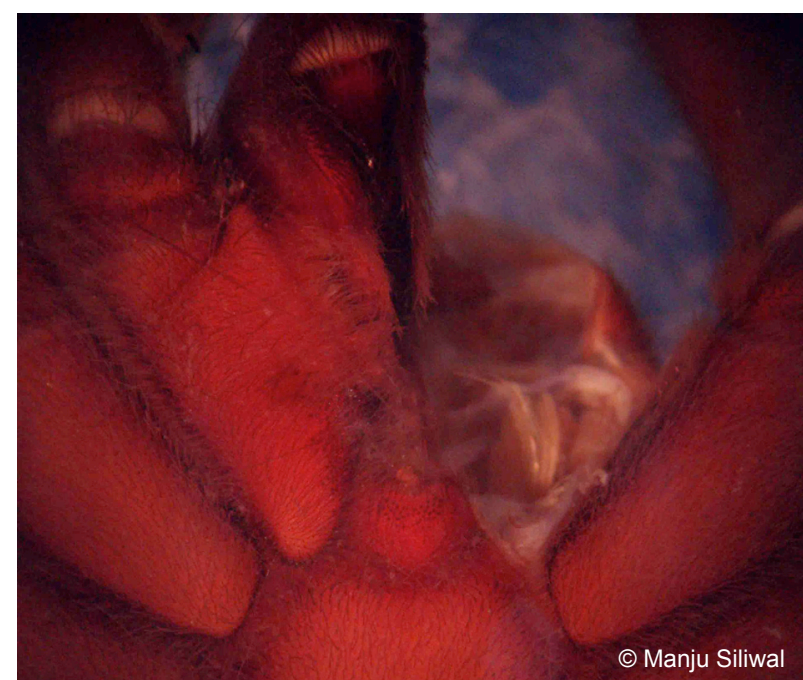

Image 8. Plesiophrictus mahabaleshwari, maxillae, ventral view

Tikader, 1977 (ZSIK, Type, number not designated) from Mahabaleshwar, Maharashtra. These spider specimens possess rastellum (Images 6-7), serrula absent (Image 8) and procurved fovea. Based on these characters, we transfer P. bhori and P. mahabaleshwari to the genus Heterophrictus. Further, the spermathecae of P. mahabaleshwari (Image 9) resemble that of Heterophrictus milleti Pocock, 1900 and based on it, we synonymise $H$. mahabaleshwari with Heterophrictus milleti.

The type specimen of Plesiophrictus nilagiriensis Siliwal et al., 2007 was also re-examined and was found that the species has transverse fovea, serrula present and absence of rastellum on maxillae. These characters validate the placement of $P$. nilagiriensis in the genus Plesiophrictus.

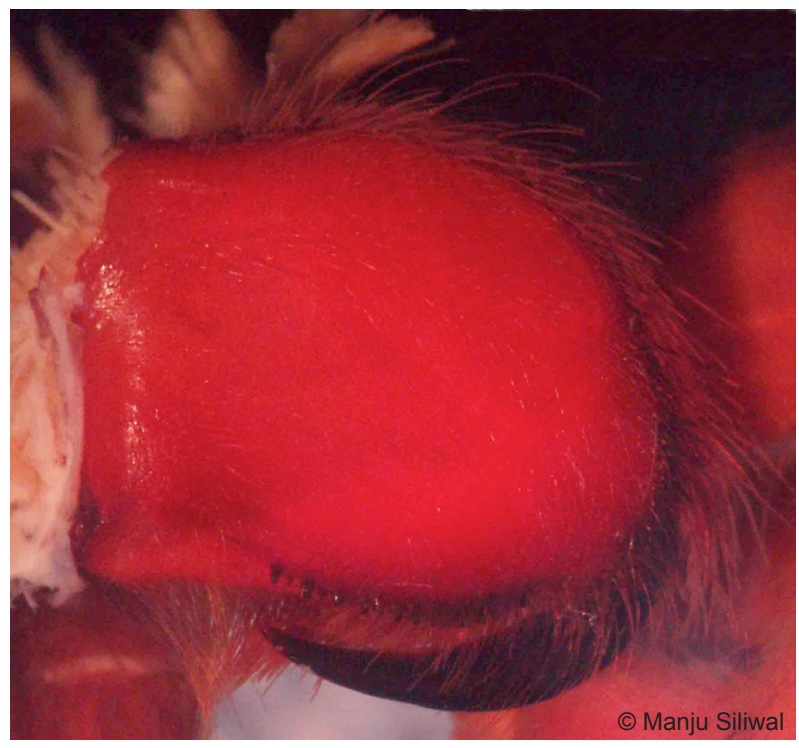

Image 7. Plesiophrictus mahabaleshwari, chelicerae, prolateral view

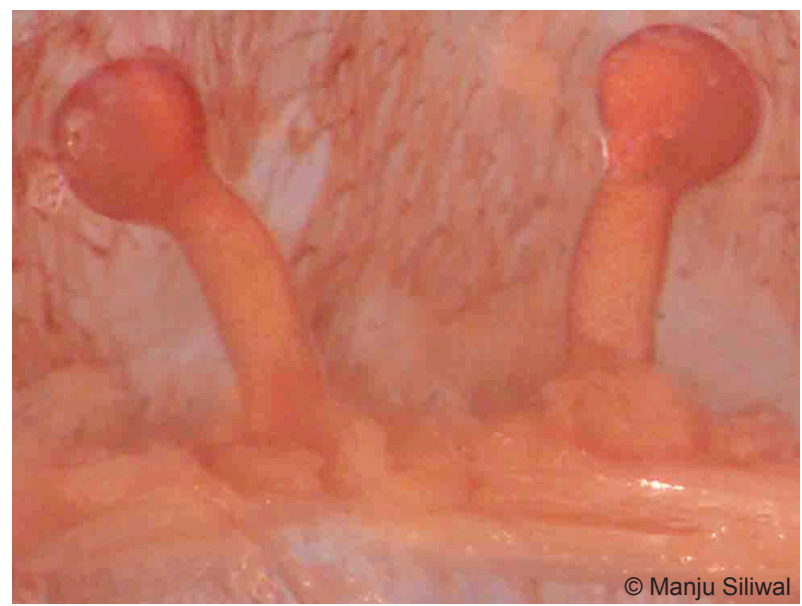

Image 9. Plesiophrictus mahabaleshwari, spermathecae, dorsal view

\section{REFERENCES}

Gallon, R.C. (2003). A new African arboreal genus and species of theraphosid spider (Araneae, Theraphosidae, Stromatopelminae) which lacks spermathecae. Bulletin of the British Arachnological Society 12(9): 405-411.

Gallon, R.C. (2005). Encyocratella olivacea Strand, 1907, a senior synonym of Xenodendrophila gabrieli Gallon, 2003 (Araneae: Theraphosidae: Stromatopelminae) with a description of the male. Zootaxa 1003: 45-56.

Gallon, R.C. (2010). On some Southern African Harpactirinae, with notes on the eumenophorines Pelinobius muticus Karsch, 1885 and Monocentropella Strand, 1907 (Araneae, Theraphosidae). Bulletin of the British Arachnological Society 15(2): 29-48.

Guadanucci, J.P.L. (2011). The genus Plesiophrictus Pocock 
and revalidation of Heterophrictus Pocock (Araneae: Theraphosidae). The Journal of Arachnology 39(3): 523527.

Raven, R. (1981). A Review of the Australian Genra of the Mygalomorph Spider Subfamily Diplurinae (Dipluridae: Chelicerata). Australian Journal of Zoology 29(3): 321363.

Raven, R.J. (1985). The spider infraorder Mygalomorphae (Araneae): cladistics and systematics. Bulletin of the American Museum of Natural History (USA): 1-180.

Siliwal, M. \& S. Molur (2009). Redescription, distribution and status of the Karwar Large Burrowing Spider Thrigmopoeus truculentus Pocock, 1899 (Araneae: Theraphosidae), a Western Ghats endemic ground mygalomorph. Journal of Threatened Taxa 1(6): 331-339.

Smith, A. M., Ed. (1990). Baboon Spiders - The Theraphosidae of Africa and the Middle East. London, Fitzgerald Publishing, 141pp.

Acknowledgment: Authors (MS and NG) are grateful to the following personnel and institutions: PCCF, Karnataka Forest Department for giving permission and logistic help during the surveys; Mr. Sunil Kumar, Deputy Conservator of Forest, Dandeli WLS, and Mr. R. Gokul, Conservator of Forests, Karwar Division for the logistic support and help during the surveys; Mr. Ramesh and Mr. Suraj Chauhan for assisting in field during the surveys: CEPF (Critical Ecosystem Partnership Fund)-ATREE (Ashoka Trust For Research In Ecology And The Environment) Western Ghats Small Grants Program for funding the tarantula project during which the new genus was found; Dr. Peter Jäger, Senckenberg Museum, Frankfurt, for providing valuable old reprints on this group of spiders; Dr. Sanjay Molur and Ms. Sally Walker, Zoo Outreach Organization, for initiating, and their support and encouragement of the Indian tarantula project; Dr. Bhaskar Acharya ATREE and Dr. Jack Tordoff, CEPF for their interest and encouragement to the Western Ghats tarantula project: Dr. Bilal Habib, Wildlife Institute of India for helping in scanning drawings. RR and MS wish to thank the Australian Biological Resources Study grant research funds for partially funding a trip to Australia for MS and so, some of the information used in this paper was obtained by MS during her visit to Queensland Museum, Brisbane. NG wishes to deeply thank Dr. Sanjay Keshari Das, Assistan Professor, Guru Gobind Singh Indraprastha University, Delhi for all the encouragement and support he provided as a supervisor for the Masters dissertation during which this spider was found

\section{Author Details and Author Contribution:}

MANJU SILIIAL has been working on spiders since 1997. She has specialized on taxonomy of primitive spiders (mygalomorphs including tarantulas) and has described many new species from India. Her main interest lies in taxonomy, ecology and conservation of Indian spiders. Her contribution to this paper is in collecting specimens, identifying the species and preparing the manuscript including taxonomy.

NeHA GuPTA is MSc in biodiversity and conservation and is very much interested in ecology and conservation of Indian spiders. For her M.Sc. dissertation, she worked on the ecology of trapdoor spiders of the family Idiopidae in Uttara Kannada, Karnataka. She was involved in the spider surveys when some of the new species listed in this paper were collected. She also assisted in taking morphometry information for most of the specimens and finalizing illustrations.

ROBERT RAVEN is world renowned expert on primitive spiders (mygalomorphs) and has experience of about 40 years in spider taxonomy. He has described 42 genera and 351 species till date from different parts of the world, predominantly from Australia. His contribution to this paper was in finalizing the text, working on language of the paper, reviewing the taxonomy of the species and providing critical inputs on various genera of Theraphosidae.

\begin{tabular}{|c|c|c|c|c|c|c|c|c|c|c|}
\hline \multirow{4}{*}{$\frac{\rho}{\pi}$} & 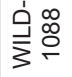 & & $\begin{array}{l}\infty \\
\stackrel{0}{0} \\
i\end{array}$ & $\begin{array}{l}\widetilde{N} \\
\text { S) }\end{array}$ & $\begin{array}{l}\hat{\infty} \\
\tilde{c}\end{array}$ & 1 & $\underset{\sim}{\stackrel{\sim}{n}}$ & $\hat{\leftrightarrow}$ & 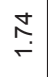 & $\stackrel{8}{\stackrel{\leftrightarrow}{\leftarrow}}$ \\
\hline & 官总 & & $\begin{array}{l}\bigotimes \\
i \\
i\end{array}$ & 勇 & $\begin{array}{l}\infty \\
\tilde{m} \\
\tilde{m}\end{array}$ & 1 & $\underset{\text { ల్ల }}{\text { ల్ }}$ & $\begin{array}{l}\text { ठั } \\
\stackrel{\rho}{\rho}\end{array}$ & 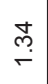 & $\stackrel{\text { to }}{\leftarrow}$ \\
\hline & 官 & & f⿱ & مె & $\begin{array}{l}\hat{f} \\
\text { eे }\end{array}$ & 1 & స్య & $\begin{array}{l}8 \\
\dot{0}\end{array}$ & $\stackrel{\rho}{\stackrel{p}{r}}$ & $\stackrel{\widetilde{o}}{\leftarrow}$ \\
\hline & 官 & & $\frac{\circ}{\dot{0}}$ & $\stackrel{\infty}{\underset{f}{f}}$ & 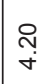 & 1 & ్ָరా & $\begin{array}{l}\stackrel{8}{\circ} \\
\stackrel{\infty}{\leftarrow}\end{array}$ & $\stackrel{\sigma}{\stackrel{\sigma}{\circ}}$ & $\stackrel{\infty}{\stackrel{\infty}{\sim}}$ \\
\hline \multirow{4}{*}{$\begin{array}{l}\geq \\
8 \\
\unlhd\end{array}$} & 官离 & & $\begin{array}{l}0 \\
o \\
0 \\
0\end{array}$ & $\begin{array}{l}\infty \\
\stackrel{0}{+} \\
\dot{\sigma}\end{array}$ & Nָ & $\begin{array}{l}R \\
\infty \\
\infty\end{array}$ & $\begin{array}{l}\stackrel{v}{\sim} \\
\text { r. }\end{array}$ & $\begin{array}{l}\stackrel{\leftrightarrow}{\infty} \\
\stackrel{m}{0}\end{array}$ & $\stackrel{\text { S }}{r}$ & 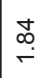 \\
\hline & 官号 & & $\underset{\infty}{\hat{\infty}}$ & $\begin{array}{l}\hat{0} \\
\text { m. }\end{array}$ & $\begin{array}{l}0 \\
0 \\
0\end{array}$ & 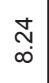 & 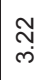 & $\begin{array}{l}\text { ले } \\
\text { ळे }\end{array}$ & $\stackrel{\circledast}{6}$ & $\stackrel{n}{\circ}$ \\
\hline & 官 & & $\begin{array}{l}0 \\
0 \\
\infty \\
\infty\end{array}$ & $\stackrel{N}{i}$ & \begin{tabular}{l}
$\infty$ \\
\multirow{1}{*}{} \\
$\dot{0}$
\end{tabular} & 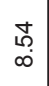 & $\begin{array}{l}\bar{\sigma} \\
\dot{m}\end{array}$ & 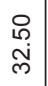 & 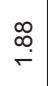 & $\underset{\sigma}{\sigma}$ \\
\hline & 官 & & $\begin{array}{l}\stackrel{0}{0} \\
\stackrel{\circ}{\circ}\end{array}$ & $\begin{array}{l}\tilde{m} \\
\text { ம் }\end{array}$ & $\stackrel{?}{\stackrel{9}{\sim}}$ & $\begin{array}{l}\stackrel{m}{+} \\
\infty \\
\infty\end{array}$ & 竝 & $\begin{array}{l}\text { đै } \\
\text { लें }\end{array}$ & $\stackrel{\mathscr{\infty}}{\leftarrow}$ & $\stackrel{q}{\stackrel{9}{r}}$ \\
\hline \multirow{4}{*}{$\begin{array}{l}\equiv \\
\text { इ } \\
\end{array}$} & 金离 & & $\begin{array}{c}\widetilde{\delta} \\
\dot{\varphi}\end{array}$ & $\underset{\sim}{\stackrel{\sim}{\sim}}$ & 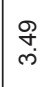 & $\begin{array}{l}\widetilde{\delta} \\
\dot{+}\end{array}$ & $\stackrel{m}{m}$ & 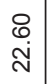 & 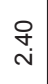 & $\stackrel{\Gamma}{r}$ \\
\hline & 官 & & 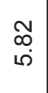 & 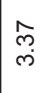 & 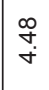 & $\begin{array}{l}0 \\
f \\
i \\
\text { in }\end{array}$ & \begin{tabular}{|l}
$\hat{\infty}$ \\
$\stackrel{N}{ }$
\end{tabular} & $\begin{array}{l}8 \\
\text { N }\end{array}$ & $\stackrel{+}{\circ}$ & $\stackrel{\infty}{\stackrel{\infty}{\circ}}$ \\
\hline & 官 & & $\frac{\infty}{\check{\omega}}$ & $\underset{\sim}{\stackrel{\sim}{+}}$ & 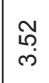 & $\begin{array}{l}\bar{T} \\
\dot{\sigma}\end{array}$ & $\begin{array}{l}\stackrel{\circ}{b} \\
\text { Ni }\end{array}$ & $\stackrel{\stackrel{\sim}{N}}{\grave{N}}$ & $\stackrel{\hat{s}}{r}$ & $\stackrel{8}{\stackrel{0}{\circ}}$ \\
\hline & 官 & & $\begin{array}{l}\dot{0} \\
\dot{0} \\
\dot{0}\end{array}$ & $\underset{\substack{\sim \\
\sim}}{+}$ & : & $\begin{array}{l}8 \\
\dot{0} \\
\dot{1}\end{array}$ & $\stackrel{\hat{N}}{\hat{N}}$ & $\begin{array}{l}\bar{N} \\
\bar{N}\end{array}$ & $\stackrel{m}{\stackrel{m}{\sim}}$ & $\stackrel{\widetilde{m}}{-}$ \\
\hline \multirow{4}{*}{$=$} & 官吕 & & 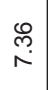 & $\begin{array}{l}\widetilde{\mho} \\
\stackrel{\sigma}{*}\end{array}$ & $\stackrel{P}{\stackrel{9}{+}}$ & $\begin{array}{l}\stackrel{0}{\circ} \\
\stackrel{m}{ }\end{array}$ & $\begin{array}{l}\hat{\infty} \\
\stackrel{N}{N}\end{array}$ & $\begin{array}{l}\infty \\
\stackrel{N}{N}\end{array}$ & $\stackrel{\mathscr{O}}{\circ}$ & $\stackrel{\curvearrowright}{\sigma}$ \\
\hline & 官兑 & & $\begin{array}{l}\stackrel{9}{m} \\
\text { i் }\end{array}$ & $\begin{array}{l}\infty \\
o \\
\infty\end{array}$ & $\stackrel{\stackrel{\infty}{\sim}}{+}$ & $\begin{array}{c}\stackrel{N}{N} \\
\dot{m}\end{array}$ & 㐫 & $\begin{array}{l}\hat{N} \\
\stackrel{\sigma}{\sigma}\end{array}$ & $\stackrel{5 ! n}{.}$ & $\stackrel{f}{\stackrel{f}{\leftarrow}}$ \\
\hline & 官 & & ڤึ? & $\underset{⿱}{+}$ & $\stackrel{+}{\text { r }}$ & $\begin{array}{l}\hat{O} \\
\dot{\sigma}\end{array}$ & $\stackrel{\infty}{\stackrel{\infty}{\sim}}$ & $\frac{8}{\stackrel{\circ}{\sim}}$ & $\stackrel{+}{\stackrel{\leftrightarrow}{r}}$ & $\stackrel{+}{\stackrel{t}{\circ}}$ \\
\hline & 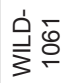 & & 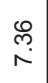 & $\underset{\kappa}{\dot{\sigma}}$ & $\stackrel{\hat{\sigma}}{\dot{\sigma}}$ & $\begin{array}{l}\mathscr{C} \\
\dot{\sigma}\end{array}$ & $\begin{array}{l}\bar{N} \\
\ddot{m}\end{array}$ & $\begin{array}{l}\stackrel{\infty}{\infty} \\
\stackrel{\sim}{\sim}\end{array}$ & $\stackrel{\infty}{\sim}$ & $\stackrel{n}{n}$ \\
\hline \multirow{4}{*}{ వ্త } & 官吕 & 产 & $\underset{\substack{N \\
\infty}}{\bar{n}}$ & 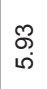 & $\begin{array}{l}m \\
m \\
0\end{array}$ & $\underset{+}{\stackrel{\sigma}{+}}$ & $\begin{array}{l}0 \\
\stackrel{\circ}{N} \\
\text {. }\end{array}$ & $\stackrel{0}{\stackrel{N}{N}}$ & O̊ & $\stackrel{m}{m}$ \\
\hline & 官 & $\frac{\text { 훔 }}{\bar{y}}$ & \begin{tabular}{l}
$\infty$ \\
\hdashline \\
0 \\
0
\end{tabular} & 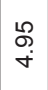 & $\begin{array}{l}0 \\
0 \\
0\end{array}$ & $\begin{array}{l}\stackrel{0}{ } \\
\dot{\sigma}\end{array}$ & 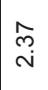 & $\begin{array}{l}\bar{\infty} \\
\stackrel{N}{N}\end{array}$ & $\stackrel{\stackrel{\circ}{\circ}}{\stackrel{\leftrightarrow}{\sim}}$ & 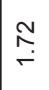 \\
\hline & 这 & $\frac{\overline{\bar{j}}}{\bar{z}}$ & $\stackrel{\bar{\Gamma}}{\sim}$ & $\begin{array}{l}\mathscr{L} \\
\infty \\
\dot{\sigma}\end{array}$ & \begin{tabular}{|l}
$\bar{\infty}$ \\
$\infty$ \\
10
\end{tabular} & $\begin{array}{l}\bar{\sigma} \\
\dot{+}\end{array}$ & 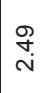 & $\begin{array}{l}\hat{\theta} \\
\dot{d}\end{array}$ & $\stackrel{\infty}{\stackrel{\infty}{\leftarrow}}$ & $\stackrel{\infty}{\stackrel{\infty}{\leftarrow}}$ \\
\hline & 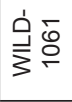 & $\frac{\overline{0}}{\bar{z}}$ & 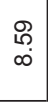 & $\begin{array}{l}\hat{6} \\
\omega\end{array}$ & $\stackrel{\infty}{\stackrel{0}{0}}$ & $\underset{\sim}{\stackrel{+}{+}}$ & $\stackrel{\infty}{\stackrel{\infty}{N}}$ & $\begin{array}{l}\bar{\infty} \\
\text { N }\end{array}$ & $\stackrel{\mathscr{Q}}{\leftarrow}$ & $\stackrel{\hbar م}{\leftarrow}$ \\
\hline
\end{tabular}

